\title{
Entre a escrita e a imagem. Diálogos com Roberto Cardoso de Oliveira
}

\author{
Etienne Samain \\ Professor do Departamento de Multimeios - UNICAMP \\ João Martinho de Mendonça \\ Mestrando do Programa de Pós-Graduação em Multimeios - \\ UNICAMP
}

\section{Apresentação}

Nosso interesse e desejo em entrevistar o professor Roberto Cardoso de Oliveira foi o de abrir um diálogo com um dos mais importantes antropólogos e hermeneutas brasileiros da atualidade, tomando como foco deste diálogo uma reflexão em torno dos respectivos papéis da escrita e da visualidade na produção do "discurso antropológico" ou, melhor dizendo, levantando a questão das "representações" que ambas promovem em vista de "interpretações" (singulares tanto complementares) dos fatos culturais. Na realidade, descobrir-se-á, nesta generosa entrevista, que mergulhamos em cinquenta anos da história da antropologia brasileira e na obra reconhecida de um autor, particularmente aberto e crítico em face da chamada "antropologia pós-moderna". Esta entrevista faz parte do projeto "A imagem dos Tükúna no contexto de um trabalho antropológico: as fotografias de Roberto Cardoso de Oliveira", desenvolvido no âmbito do curso do Programa de Pós-Graduação em Multimeios na Unicamp, por João Martinho de Mendonça, sob a orientação de Etienne Samain e com o apoio da Fapesp. Teve início com um registro oral 
Etienne Samain e João M. De Mendonça. Diálogos com Roberto Cardoso de Oliveira

efetuado em Brasília, em 21 de maio de 1998, tendo recebido, no intervalo, de ambas as partes, a presente edição complementada com novas perguntas e reformulações.

Etienne Samain: Num artigo intitulado "Mestres precursores", que Mariza Corrêa publicou no livro organizado pelo senhor em 1995 (Estilos de Antropologia), ela escreve esse texto bastante esclarecedor: "Durante muito tempo os antropólogos foram personagens quase invisíveis, sempre presentes por detrás das máquinas que eles manejavam, nas frases de seus livros, e, às vezes, na capa e na contra-capa deles". Sem dúvida, devemos entender essa frase com certa dose de humor. Resta que, para mim, ela revela bem o paradoxo, talvez a ambigüidade do ofício do antropólogo, a saber: ele fica sempre presente por detrás de suas câmeras ou atrás das frases dos seus livros... mas ele não deve se mostrar... em nome da objetividade, ele não tem de aparecer quando, ao mesmo tempo, ele tem como objetivo o de revelar o outro. Uma postura pelo menos singular, muito diferente da de um jogador de futebol, que tem precisamente que se expor para que o jogo possa existir... A minha pergunta: qual seria sua reação diante desta colocação?

Roberto Cardoso de Oliveira: Eu conheço bem a professora Mariza Corrêa e sei de seu interesse pela antropologia brasileira, inclusive graças ao fato de ela ter criado um programa, que você conhece, sobre a História da Antropologia no Brasil, e para o qual acabei sendo convidado a participar. Inicialmente, tive por tarefa servir de seu informante e lhe concedi uma longa entrevista, gravada e filmada. Aliás, uma das razões de minha ida para a Unicamp foi em decorrência desse convite que ela me fez, de dar aquele depoimento, como este que estou dando agora, mas um depoimento no programa de História da Antropologia Brasileira.

Ela queria convidar antropólogos, já de uma certa idade. Para mim, ao menos, dizia que eu era o mais jovem que ela convidava. Mas isso foi em 84... Fui dar então essa entrevista para o programa, que resultou num vídeo, em que eu falava diante da câmera, em que se registrava também a imagem, não só a fala. Ela tem esse material nos seus - o que eu chamaria de - 
"arquivos fotográficos, fonográficos e cinematográficos implacáveis". Essa é a Mariza, excelente pesquisadora, com sua ânsia de registrar tudo, de documentar a antropologia que se fez e que se faz no Brasil.

E para mim, como estava dizendo, foi interessante porque ao terminar a entrevista, ela e o então diretor do IFCH (Instituto de Filosofia e Ciências Humanas), professor André Villa-Lobos, me convidaram para trabalhar na Unicamp, sabendo que eu já estava interessado em sair eventualmente da UnB. Fiquei de dar uma resposta depois que voltasse do Canadá, pois estava com viagem marcada para um encontro com colegas do Departamento de Antropologia da Université de Montréal, para onde acabei indo, e depois voltei aos Estados Unidos para mais uma visita a Universidade de Harvard. E acabei aceitando. Então, não deixa de ser interessante dizer que o meu relacionamento com a Unicamp começou com um registro desse tipo, e, agora, que já estou aposentado, como Professor Emérito da Unicamp - que, por sinal, graças à recomendação generosa de meus colegas do Instituto de Filosofia e Ciências Humanas, me concedeu esse título -, começo 1998 já dando um outro depoimento (risos), pelo menos não mais sendo filmado, apenas ouvido! O que me deixa bem mais tranqüilo...

Etienne Samain: ... para outros colegas da mesma Unicamp...

Roberto Cardoso de Oliveira: Para outros colegas da mesma Unicamp! Não é?... É interessante isso... e é nesse contexto que eu dou agora o meu depoimento e tento responder à sua pergunta.

É curioso verificarmos que na história da antropologia, a ausência do antropólogo está mais no texto do que na imagem. Recordo-me que o antropólogo quase sempre dá um jeito de fazer publicar a sua imagem. Nós vemos isso em relação a vários antropólogos famosos, desde Malinowski, que sempre tem uma forma de ser registrado, além de muitos outros.

No Brasil, Eduardo Galvão sempre saía nas suas fotos... Darcy Ribeiro saía... O Darcy ainda é mais explicável pela sua postura narcisística... ou "darcysística"... diante do mundo da antropologia. Mas o Galvão, que não 
era um narciso, aparecia também. Então há sempre esse hábito. Eu mesmo apareço em vários... Nos meus livros sobre os Terêna, ou sobre os Tükúna, acabo aparecendo também. Porém, o que havia era, ao contrário, um hábito ou mesmo um padrão do antropólogo não aparecer no texto, a não ser muito subrepticiamente, em notas de rodapé. Isso passou a ser atualmente um tema de reflexão sobre a própria retórica do texto e da imagem.

Tenho a impressão de que a imagem é menos comprometedora, porque nela você tem a prova de que esteve efetivamente lá, no campo... $\mathrm{O}$ "be there"... O "esteve lá" é registrado graças a uma pura e simples imagem. Já o "ser registrado no texto" começa a ser uma questão posta muito mais recentemente na história da antropologia, sobretudo com a chamada antropologia pós-moderna que, muitas vezes, exagera o "estar" no texto, fazendo com que, às vezes, um texto de antropologia passe a ser um texto intimista: o próprio pesquisador muitas vezes falando mais de si do que do Outro!!!

Mas nesse "falar de si" e o certo pejo de "falar de si" nos textos mais tradicionais de antropologia que, aliás, são os meus textos etnográficos, uma vez que foram escritos nos anos 50 e nos anos 60 - já faz bastante tempo - nessa época, na forma de fazer antropologia, havia um cuidado de não se misturar com o objeto sobre o qual se refletia e investigava.

Ora, vejo hoje, evidentemente com os olhos atuais de uma antropologia que se integra num horizonte epistemológico bem mais moderno, que esse cuidado de não contaminar a realidade estudada com a sua presença, isso faz parte de uma grande ilusão... Uma grande ilusão gerada pelo objetivismo, que entendo como uma forma perversa de se procurar alcançar a objetividade. O objetivismo pode ser considerado como uma ideologização da procura costumeira de objetividade, que deve sempre haver em todo trabalho científico, mas não com esse exagero a ponto de se acreditar na possibilidade de uma objetividade absoluta; que, por sua vez, não deixa de ser uma questão metafísica.

Ora, exorcizada essa idéia da objetividade e passando a considerar que ela é sempre relativa -dependendo da perspectiva do sujeito cognoscente, 
Revista de Antropologia, São Paulo, USP, 2000, v. 43 nº 1.

quer dizer, do investigador -, você pode hoje entrar no texto muito mais à vontade. O idioma francês possui uma palavra bem mais adequada para a expressão "à vontade", usa o termo “aisance"...

Então, hoje você se permite entrar no texto naturalmente, porque a antropologia tornou-se um exercício reflexivo também. Você pode exercitar a reflexão, a partir do lugar que você ocupa, quer dizer, não há produção de conhecimento que não se enraíze no seu produtor, e esse produtor está situado, quer dizer, não existe texto "dessituado", o texto "dessituado" é profundamente ilusório, pois é um texto artificial.

Acho, portanto, que o grande passo que a antropologia deu nesses últimos quinze, vinte anos, foi colocar no seu lugar a busca de objetividade, que passa a ser, do meu ponto de vista, uma idéia reguladora... Você não pode começar uma pesquisa dizendo "éimpossível ser objetivo"... seria a mesma coisa de procurar fazer uma pesquisa dizendo que é inviável falar em verdade. Ora, quando você fala em "verdade", você está trabalhando num plano quase metafísico, que coloca "o que é verdade?".

Mas, se você passa a pensar e reduz a questão da verdade a uma questão de veracidade, que já é produto de um consenso entre pares, no caso, entre antropólogos - consenso que é gerado no seio de uma comunidade local, a partir de um debate numa universidade, até um debate regional, nacional, até internacional, no nível planetário -, então nós podemos ter um certo controle do que chamamos de veracidade através da relação dialógica, que é uma contribuição da própria hermenêutica à antropologia moderna. E não apenas para ela...

Agora, quando você me coloca a questão do autor no texto, ela está muito presa a uma concepção da antropologia em que a objetividade devia ser procurada a todo custo, inclusive a custo da presença do ponto de vista do autor. Aliás, o ponto de vista do autor não é sequer questionado, é dado como óbvio que o autor busca a objetividade, mas nunca é apresentada a discussão de que essa objetividade que ele busca ter não é senão o resultado de uma perspectiva gerada do lugar do qual ele fala... De onde ele fala? Ele fala no âmbito de um paradigma determinado, do 
Etienne Samain e João M. de Mendonça. Diálogos com Roberto Cardoso de Oliveira

lugar onde trabalha, de uma instituição, lugares que têm o poder de determinação na construção do objeto. Nós sabemos que o próprio objeto da antropologia não é um objeto inerte, não está lá; o objeto nasce da relação com o sujeito cognoscente com o objeto cognoscível e portanto você o constrói... Entendo que nessa construção você deve ter a coragem e a habilidade de se inserir no texto - naturalmente sem pesá-lo com sua biografia - tanto quanto é legítimo você se inserir como imagem.

Etienne Samain: Já que falamos de "construção", gostaria de apontar para um dos seus recentes artigos : "Ver, ouvir..."

Roberto Cardoso de Oliveira: Que publiquei em sua primeira versão, intitulada "Olhar, ouvir, escrever", como Aula Inaugural de 1994 dos Cursos de Pós-Graduação do Instituto de Filosofia e Ciências Humanas da Unicamp; e uma segunda versão ampliada, já com novo título, "O trabalho do antropólogo: olhar, ouvir, escrever" que a Revista de Antropologia da USP publicou em 1996, foi incluída em meu livro $O$ trabalho do antropólogo, de 1998, título, como vê, inspirado no artigo...

Etienne Samain: ... Exato. Colocando-nos no campo da antropologia social, ninguém contestará o fato de que o ato da observaçãoé e permanecerá fundamental à disciplina. Levanto, todavia, essa questão aparentemente banal: até que ponto os antropólogos se deram e se dão conta da natureza e da singularidade desse ato comunicacional? O que significa "observar"? Mas, também, "o que observar? como observar?", quando se trata de fazer antropologia... Penso sempre neste óbvio: sem meios de comunicação não se teria sequer uma sociedade capaz de ser observada, contada, descrita, estudada... e os antropólogos não existiriam! Levanto, então, essas questões na medida em que, como antropólogo, o problema da comunicação pareceme tornar-se cada vez mais importante e central se quisermos, ainda, pensar numa antropologia das sociedades e dos homens de amanhã: homens cujas relações e interações serão definidas a partir de novos parâmetros e 
Revista de Antropologia, São Paulo, USP, 2000, v. 43 nº 1.

suportes comunicacionais; sociedades que se organizarão em novas dimensões, a partir de novos modelos e de novas estruturas comunicacionais.

Voltemos ao seu artigo "Olhar, ouvir, escrever". A antropologiareconhece o senhor - se faz e se dá através dos nossos sentidos: o "olhar", primeiro, o "ouvir", depois, ... resta que, no seu artigo, prevalece o fato de que o verdadeiro ato antropológico se realiza, após ter feito tudo isso... quando, com base nas observações (visuais e/ou gravadas), com base nas anotações dos seus cadernos de campo, o antropólogo, enfim, pode recolher-se na sua própria residência, no laboratório da "escrita" (como a gente poderia falar de um laboratório da "imagem") para pensar e elaborar um discurso escrito... aliás um discurso que tem de ser pensado e encarado em face de necessárias discussões futuras com outros colegas ou pares. Nessa perspectiva que respeito, mas que, para mim, permanece pelo menos questionável, pergunto-me o que sobra do trabalho originário de observação ou de anotações preliminares (até intempestivas) dos cadernos de campo, quando, passando por uma série de filtragens laboratoriais, de eliminações sucessivas (tais ou tais dados sendo considerados sem "importância", tais outros, "detalhes julgados irrelevantes ou apenas secundários" etc...), este trabalho preliminar é reconstruído (isto é, interpretado mais uma vez) sob a égide da única escrita e de suas potencialidades lógi(sti)cas peculiares.... para um círculo de iniciados? Não contesto o papel heurístico formidável da escrita. Procuro apenas situar novamente os papéis comunicacionais dos nossos sentidos na elaboração e na construção do ato antropológico. Como o senhor entrevê tal problematização, hoje?

Roberto Cardoso de Oliveira: Evidentemente estou falando de um lugar que ocupo, quer dizer, como antropólogo social, como etnólogo e que tem como seu meio de comunicação o discurso escrito. Claro que tem o discurso oral, de que eu me valho na minha função de professor e na minha comunicação em situações e debates interpares, que se dá em seminários etc... É onde eu posso checar o meu conhecimento em tal e qual área em antropologia: no debate com meus colegas. Acho que só faz sentido - qualquer disciplina - se ela busca comunicação. Não há o 
intelectual solitário. Mesmo o intelectual solitário está dialogando com os autores, portanto ele está sempre exercitando o diálogo.

Logo, a forma de expressão que você tem em ciências humanas - não só em antropologia - é realmente o texto; é a forma, por excelência, que o antropólogo usa tradicionalmente. Agora, na medida em que você, ao meu ver, incorpora na linguagem textual do antropólogo uma linguagem fotográfica, uma linguagem através de imagens, ela é uma linguagem também. Então, quando falo da construção do texto, não excluo também a imagem interpretada como, não sei se seria correto dizer, um discurso imagético. Um discurso, por exemplo, usando um filme.

Hoje é muito mais fácil você ir ao campo e trabalhar com uma câmara de vídeo... Então, a facilidade não se compara com as dificuldades que tinha, para dar um exemplo, o Heinz Foerthmann quando foi fazer o grande documentário que fez sobre o Funeral Bororo e que, infelizmente, não saiu de sua forma inacabada de "copião"! Como fez isso? Soube disso quando trabalhávamos juntos no Museu do Índio e assisti várias vezes a sua projeção. Ele trabalhou, para gravação do som na aldeia Bororo, com dois gravadores de fio metálico; cada gravador pesava tanto que tinha de se valer de duas mulas, cada uma carregando um gravador de fio e ainda outras mulas mais para o transporte das baterias. E mesmo assim conseguiu realizar o documentário brilhantemente, trabalhando com uma máquina de filmar normal de cinema, para $35 \mathrm{~mm}$. Então você pode imaginar o que é levar essa tralha toda para fazer um filme etnográfico; e, com tudo isso, sem assustar os índios, imersos em seus rituais fúnebres... Essa era uma das dificuldades de se fazer um filme etnográfico com a tecnologia da época!

Então, quando o Foerthmann realizou esse documentário? Foi no final dos anos 40. Mas até o começo dos anos 50, quando o conheci, ainda se usava esse equipamento, e que ainda não tinha sido abandonado numa das salas do Museu. Pode-se dizer, portanto, que até meados dos anos 50 os equipamentos eram extremamente pesados e de difícil utilização na prática da documentação etnográfica. O que compensava era a notável habilidade do Foerthmann em se relacionar com os índios. 
Lembro-me que da primeira vez que conheci um gravador altamente sensível foi na mão de um psicólogo-lingüista muito competente, Eric Lenneberg, de Harvard - e que haveríamos de nos tornar grandes amigos -, que me procurou no Museu Nacional em princípios dos anos 60. Eu era diretor da Divisão de Antropologia e ele queria meu apoio para gravação do "blá-blá-blá" de crianças índias, porque queria ver como crianças de 3, 4 anos de idade "falavam" e comparar o "blá-blá-blá" com o de crianças ocidentais e de outros grupos tribais.

Ele me mostrou uma máquina, que era grande - se a compararmos com os gravadores portáteis de hoje -, dotada de um microfone extraordinariamente sensível que, preso ao pescoço da criança, ao mesmo tempo que protegido por uma pequena grade para evitar quebrá-lo, era usado por horas nas pequenas crianças - microfone que elas podiam manipular como se fosse um brinquedo... Era uma pesquisa bastante complexa, e para mim, vendo o equipamento, era algo de outro mundo, era uma coisa moderníssima, porque você tinha um instrumento muito sofisticado para a época, ainda que meio desconfortável para o pesquisador carregar consigo.

Com esse exemplo, permito-me imaginar que enquanto houve um desenvolvimento muito maior do discurso escrito na antropologia, o discurso imagético, ou o sonoro, teve uma dificuldade muito maior, provavelmente por questões técnicas, por causa de uma tecnologia ainda incipiente. Penso que o grande desafio hoje é fazer com que a distância entre o discurso feito por imagens, portanto uma linguagem feita de imagens, e a linguagem escrita se aproximem mais. Entendo que isso seja um programa de trabalho importantíssimo. Tenho a impressão de que o que vocês fazem lá, em seu Departamento (de Multimeios da Unicamp), é uma contribuição a fazer com que o "gap", esse abismo que existe entre essas duas linguagens, diminua. É algo com o qual só pode ganhar a própria antropologia.

Quando falo da escrita, do "escrever", tenho também razões de natureza docente. É que falo também como professor. Aliás, você vai ler no prólogo desse livro ( $O$ trabalho do antropólogo), que me coloco mais na posição de professor do que na de pesquisador. Nele trato o "escrever" como 
ato cognitivo fundante da antropologia, pois procuro mostrar que o ato de escrever não é apenas um ato simplesmente expositivo. Você não escreve apenas para comunicar. Claro que a questão da comunicação está posta, mas você escreve porque você está escrevendo, pensa, reflete! E isso é, então, uma forma de produção de conhecimento em si mesma, para a qual eu chamava a atenção dos alunos, no sentido de que eles nunca esperem "saber tudo" para, só então escrever; e isso porque eles só vão saber não digo tudo, mas o necessário para produzir sua tese, seu texto - no próprio processo de produção do discurso escrito, isto é, na medida em que não esperem muito para textualizar suas observações etnográficas, suas interpretações. O escrever e o pensar são dois atos extremamente integrados e é por isso que ponho muita ênfase na articulação de ambos nesse texto. Nele quis mostrar como o antropólogo podia revelar um pouco dos três atos fundantes do exercício da antropologia, o ato de olhar, o ato de ouvir, o ato de escrever, e tentando fazer com que cada um desses atos pudesse ser tematizado, isto é, questionado pelos estudantes. Que interrogasse sobre eles. Fossem induzidos a estranhá-los. Que não se olha impunemente, que não se ouve impunemente e muito menos se escreve impunemente. Meu intuito era mostrar um pouco essa relação, essa dinâmica desses três atos fundadores do exercício da antropologia.

Etienne Samain: Fiz a pergunta porque, de fato, seu artigo dava ênfase ao escrever. Tenho o sentimento de que, indo para o campo hoje, o senhor iria, certamente com os meios técnicos que possuímos, mais inquieto e consciente do poder complementar dessas imagens (fotográficas, cinematográficas, videográficas ou digitais), nas suas respectivas tentativas de "representar"... Pois, tanto a escrita quanto a(s) imagem(s) nunca serão outra coisa a não ser "representações de representações", isto é, seqüências de atos interpretativos...

Roberto Cardoso de Oliveira: Concordo, e quem coloca isso muito bem, a saber, a questão da interpretação, não é um antropólogo, é um filósofo, é Paul Ricoeur. Ele mostra que há uma dialética entre o "explicar" 
Revista de Antropologia, São Paulo, USP, 2000, v. 43 nº 1.

e o "compreender". Mostra que o que ocorre é uma interpretação compreensiva, diferente de uma interpretação explicativa. Uma interpretação "explicativa" está preocupada com causas... por exemplo, de A para B, que A causa B, que B causa $C$, então estabelece seqüências, e comprova isso gerando, inclusive, proposições analíticas com ambições nomológicas. Já o compreender, contido na expressão "interpretação compreensiva”, seria um esforço de se transcender os métodos eventualmente usados. A compreensão atuaria, assim, segundo Ricoeur, numa área não coberta por métodos, especialmente os métodos empírico-analíticos que povoam o espaço das ciências sociais. E Ricoeur vai mostrar que é uma área em que se trabalha no excedente de sentido, que ele denomina com a expressão francesa surcroît de sens. O que seria um excedente de quê? Excedente dos métodos. O método, à sua maneira, sempre "mede". A mensuração, qualquer que seja ela, mede o que o método pode medir. Evidentemente que mesmo que você use um elenco de métodos, sempre há algo que o método não mede, então isso aí é o surcroît de sens.

Esse excedente de sentido você capta pelo exercício da hermenêutica, graças à compreensão, essencialmente não-metódica - para me valer ainda de Ricoeur. Agora, como entra a fotografia? Acho que ela entra nesse processo, primeiro num nível de aide-mémoire. Quer dizer que você registra e depois você olha a fotografia, e, no olhar a fotografia, você se habilita a uma presentificação do passado. Então, essa presentificação é um ato hermenêutico por excelência, porque você re-interpreta o que a máquina já interpretou - ela também interpreta, ao modo dela focalizar, porque é um artefato.

Já a realidade que ela captou é função das potencialidades do artefato tecnológico, mas com isso você se transporta, e é isso que acho importante. Você se transporta ao momento em que você fotografou e a sua memória é avivada. E nesse sentido de avivar a memória, você passa a fazer uma leitura daquele momento captado pela máquina fotográfica ou pelo vídeo. Você vai fazer uma leitura, certamente diferente, do que você faria à época da pesquisa, como no meu caso, por exemplo, quarenta anos depois de ter fotografado algo de meu interesse etnográfico. Por quê? Porque em 
Etienne Samain e João M. De Mendonça. Diálogos com Roberto Cardoso de Oliveira

quarenta anos o antropólogo mudou muito, não só ele mudou, a antropologia também mudou.

Logo isso permite a você, como uma forma de presentificar o passado, fazer uma releitura desse passado. Acho que combinando os procedimentos imagéticos com o discursivo, cujas imagens ou representações estão na câmera fotográfica ou registradas no diário de campo, você conta com dois elementos que permitem duas leituras que seriam, nesse caso, complementares - e eu nem diria que uma seja melhor do que a outra. Certamente podem ser complementares, porém isso não chega a ser uma questão teórica, mas simplesmente um problema prático, de prática interpretativa.

Etienne Samain: Gostaria de abrir um parêntese: será que o senhor eventualmente consentiria pensar em "dois modos distintos do pensamento científico", como diria Lévi-Strauss, "dois níveis estratégicos, onde a natureza deixa-se atacar pelo conhecimento científico: o primeiro, aproximadamente ajustado ao da percepção e da imaginação, e o outro, deslocado; como se as relações necessárias, objetivo de toda ciência, pudessem ser atingidas por dois caminhos diferentes: um muito próximo da intuição sensível, o outro mais afastado" ( 1976).

Roberto Cardoso de Oliveira: O “selvagem” seria o imagético?

Etienne Samain: E o outro, o "lógico", seria representado pela escrita...

Roberto Cardoso de Oliveira: Em termos, porque o pensamento dito selvagem não deixaria de ser lógico para Lévi-Strauss; seria apenas nãodomesticado pelos procedimentos lógicos inerentes ao pensamento ocidental, o qual, para nosso autor, seria o melhor exemplo de "la pensée domestiquée". Isso não quer dizer que a imagem não possa ter um lugar privilegiado no "pensamento selvagem". Pois antes da escritura a memória humana não era caracteristicamente visual? Mas o que eu acho é que o diário de campo tem uma função que transcende a mera observação. $\mathrm{O}$ 
Revista de Antropologia, São Paulo, USP, 2000, v. 43 nº 1.

discurso que você produz no diário de campo é mais do que aquele que você produz numa caderneta de campo, em que você registra curtas observações, dados quantificáveis e alguns diálogos sumários que lhe parecem essenciais.

Como é que você escreve o diário de campo? Aí é que está. Implica uma fenomenologia do diário de campo, não é? Você escreve o diário geralmente à noite, quando já trabalhou o dia inteiro e anotou na caderneta. No diário você tem o primeiro distanciamento, então você tem o primeiro momento de reflexão. Não é bem a separação que Geertz faz entre o "be there" e o "be here", vendo neles uma diferença radical. Porque no "be there", no "estar lá", você tem também momentos de reflexão, e isso aparece no diário. Tenho em partes dos meus diários pequenos pré-artigos. Pré-artigos que elaboro, faço esquemas básicos para desenvolvimento futuro. E estou muito junto do evento observado, daquele fato registrado, os insights que tenho posso colocar no diário.

Então o diário, parte dele, quando você não registra apenas datas e o que você fez no dia, quando você põe o material etnográfico dentro dele, passa a ser muitas vezes um pré-texto. Eum pretexto para um artigo, como sugere a homofonia das palavras...

Lembro que tenho dois artigos sobre os Tükúna escritos em grande parte no campo. Não sei se você leu, inclusive, para o seu trabalho. Foram republicados naquele meu livro Enigmas e soluções: exercícios de etnografia e de crítica. Pois é, dois artigos, um sobre o "totemismo" e o outro sobre "aliança interclânica". Esses dois artigos foram, praticamente, pensados no campo. Então, no diário você faz elaborações, reflexões, que não consegue fazer com uma imagem.

Mas acho que a imagem passa a ter um peso muito grande, sobretudo se você toma por referência esse artigo, digamos, esse artigo conhecidíssimo do Geertz sobre a briga de galos. Escrevi um pouco sobre isso num pequeno ensaio, originalmente uma conferência, publicado como apêndice em meu livro Sobre o pensamento antropológico, com o título "Leitura e cultura de uma perspectiva antropológica". Evoco a experiência de Geertz e falo sobre minha experiência com os Terêna, ao reler o que estava 
Etienne Samain e João M. De Mendonça. Diálogos com Roberto Cardoso de Oliveira

registrado em meu diário de campo sobre minha participação num ritual de cura realizado por um koixomuneti Terêna, um importante xamã da aldeia Cachoeirinha ou Bookoti, como é chamada em idioma xané, significando "barulho d'água".

A experiência foi a seguinte: me submeti a uma cerimônia de xamanismo para saber como funcionava. O xamã começou sua função de curador cantando e dançando em torno de mim, deitado no centro da maloca, depois parou, pôs a boca na minha barriga e, por sucção, pois eu havia dito que estava com dor de barriga, ele simulou tirar uma pequena pedra que, vitorioso e digno, mostrou ao admirado público presente. Então, relendo o diário, escrito há trinta ou quarenta anos, passo a reinterpretálo vendo aquilo que sofri com as artes de prestidigitação do xamã Gonçalo - lembro-me até agora do nome do xamã - teve uma significação que me passara despercebida: o acontecimento fez com que conseguisse uma aceitação pela sociedade Terêna que eu jamais imaginara.

Esse dado era muito importante e percebi isso lendo Geertz, quando ele mostra que, com a sua participação no caso da briga de galos, de ele fugir da polícia e tudo mais, só então começou a ser aceito pela comunidade. Há claramente essa "aceitação pela comunidade", na etnografia que ele fazia da briga de galos. Comigo deu-se a mesma coisa depois de passar pelas mãos do xamã.

E como se deu isso? Comecei a ser convidado a entrar nas casas, até então vedadas a mim. Isso quer dizer que ficava na área pública e passei a entrar na área privada. Enquanto me tratavam muito bem fora, eu dava brindes, conversava, entrevistava. Depois já me chamavam para dentro das casas, convidando para tomar o "tereré" (um mate frio) ou chimarrão: "Vem tomá um maté dotô, entra" - convidavam amistosas as velhas Terêna.

Mas só percebi isso com a presentificação do passado, com os olhos novos da antropologia. A imagem neste caso passa a ser extremamente sedutora porque você passa a olhar... Por exemplo, você vê, às vezes, coisas das quais você já tinha esquecido, passa a rever isso, a reviver... $\mathrm{O}$ aide-mèmoire, como texto ou como imagem, é, pois, de grande valia para a construção do discurso etnológico. 
Revista de Antropologia, São Paulo, USP, 2000, v. 43 nº 1.

João Martinho de Mendonça: Sobre essa relação quero evocar um artigo de Christopher Pinney intitulado "A história paralela da antropologia e da fotografia", traduzido ao português em 1996 por Ricardo Quintana e Patrícia Monte-Mór (Cadernos de Antropologia e Imagem, n. 2), no qual é mencionada uma analogia entre o trabalho de campo antropológico e a exposição fotográfica. Pinney diz: "Assim, a exposição do antropólogo aos dados ocorria durante um período de inversão da sua realidade normal, uma situação que é formalmente análoga à produção do negativo fotográfico, quando os raios de luz essenciais que garantem a verdade indexical da imagem incidem sobre a emulsão do negativo (...). A fotografia revela-se, assim, muito menos e muito mais importante do que havíamos pensado. $\mathrm{O}$ antropólogo trouxe para sua própria pessoa as funções de uma placa de vidro, ou de uma tira de filme que, tendo sido preparada para receber e registrar mensagens em forma de negativo durante um momento de exposição no 'campo', possui a capacidade, após um processo apropriado, de apresentá-las em um estado 'positivo' na monografia etnográfica".

Nas questões anteriores o senhor sugeriu uma complementaridade entre os diários de campo e as fotografias, isto no sentido de que perfazem juntos uma memória sempre passível de novas interpretações e possibilitam o ato hermenêutico da presentificação do passado. São suas palavras: "Você escreve o diário geralmente à noite, quando você já trabalhou o dia inteiro e anotou dados na caderneta. No diário você tem o primeiro distanciamento, então você tem o primeiro momento de reflexão". Parece-me que a escrita do diário de campo evoca uma sensibilidade muito especial, os acontecimentos cotidianos vivenciados à luz do dia estão ainda bastante presentes para o pesquisador assim como também as dúvidas e inquietações. À noite, talvez numa hora de recolhimento, o antropólogo registra no diário suas impressões, representadas através da escrita.

No sentido de desenvolver a analogia que apontei acima, poderíamos pensar este "primeiro momento de reflexão" como uma espécie de primeira revelação, em que se tem já um "embrião" (lembrando as suas palavras), como uma imagem em negativo, daquilo que será muitas vezes um artigo 
Etienne Samain e João M. De Mendonça. Diálogos com Roberto Cardoso de Oliveira

ou parte da monografia (imagem em positivo)? Assim, se o fundamento mesmo do trabalho de campo antropológico incorpora metaforicamente o modelo do processo fotográfico como sugere Pinney, a fotografia em si deixa de ter importância diante da intensidade evocada pela exposição do próprio antropólogo ao campo (em oposição à película sensível bidimensional, um ser humano complexo, com sentidos múltiplos, numa dimensão real)? O que acha da comparação?

Roberto Cardoso de Oliveira: Em primeiro lugar digo que gostaria de ler esse artigo de Pinney, pois não o conheço. E pensar sobre ele. Mas, desde já, segundo sua apresentação das idéias do autor, sou levado a concordar em tese sobre esse paralelismo. Apenas acrescentaria que o diário escrito horas depois do observado ou do "experienciado", se já é portador de uma leitura secundária (pois não imediata, mas mediatizada pelo distanciamento de horas e, sobretudo, pelo tempo maior de reflexão), o que se poderia dizer então de re-leituras feitas anos depois - ou, como diria Geertz - no conforto dos gabinetes universitários? Esse distanciamento - ou mesmo qualquer distanciamento é o que me parece mais fecundo para a interpretação hermenêutica. Distanciamento de tempo e de lugar - da cena original vivida pelo antropólogo graças à observação participante.

João Martinho de Mendonça: Professor, voltando agora à primeira questão, no momento em que o senhor diz que acaba aparecendo também nos seus livros sobre os Tükúna (O índio e o mundo dos brancos -1964) e Terêna (Do índio ao bugre - 1960). Até onde pudemos observar, não encontramos imagens suas nas obras referidas. Nota-se ainda que, passando ao seu trabalho de doutorado Urbanização e tribalismo: a integração dos Terêna numa sociedade de classes (1968), as imagens fotográficas deixam de fazer parte de seus livros para reaparecerem numa publicação de 1988, A crise do indigenismo, em que o senhor aparece numa fotografia sob uma árvore gigantesca.

Creio que podemos constatar aqui dois tipos de problemas. Um que seria a ausência ou escassez de imagens fotográficas (restritas às funções 
Revista de Antropologia, São Paulo, USP, 2000, v. 43 nº 1.

de ilustração e de evocação da experiência de campo) nas monografias publicadas no período em questão, marcado pela consolidação do paradigma estruturalista. $\mathrm{O}$ outro seria a ausência do antropólogo no texto e nas (poucas) imagens fotográficas (nem sempre publicadas) produzidos no mesmo período, remetendo portanto à dimensão autoral nos trabalhos antropológicos. O senhor poderia nos esclarecer um pouco mais sobre estas questões?

Roberto Cardoso de Oliveira: Inicialmente, uma correção: o livro Do índio ao bugre, que tem por subtítulo $O$ processo de assimilação dos Terêna, é de 1976, portanto é a segunda edição, feita pela Livraria Francisco Alves, que quis um título mais charmoso, mais vendável, que a primeira edição realizada pelo Museu Nacional, em 1960, intitulada $O$ processo de assimilação dos Terêna - para a Francisco Alves um título muito acadêmico... Pois bem. Na primeira edição há 14 fotos, todas de minha autoria e cuidadosamente escolhidas por mim para o volume. Destas fotos apenas duas não foram incluídas na segunda edição. E certamente porque não foram encontradas em tempo hábil. Quanto à minha tese doutoral que se transformou alguns anos depois no livro Urbanização e tribalismo, as fotos só não integraram o volume para não encarecê-lo por causa do espírito econômico do Jorge Zahar, meu editor; e pela ausência delas no livro, sua versão castelhana, publicada no México em 1972, também ficou sem ilustração fotográfica. Já com relação às quatro edições de $O$ índio e o mundo dos brancos, publicadas respectivamente pelas editoras Difusão Européia do Livro, Livraria Pioneira, Editora da Universidade de Brasília e Editora da Unicamp (por esta última, uma edição comemorativa dos 30 anos de aniversário do livro), a seleção das fotos deveu-se às editoras, salvo no que se refere à primeira edição de 64. Como cada uma das edições foi realizada por uma editora, a escolha dos negativos foi imposta pela maior ou menor disponibilidade dos mesmos.

Mas essas explicações não respondem uma outra parte de sua pergunta: se a entendi bem, você quer encontrar uma razão teórica, estruturalista, 
para que eu, como autor, tenha desejado me esconder no texto, numa atitude no mínimo ilusória inspirada num cientificismo exacerbado... Talvez seja um exagero meu, porém valho-me do exagero para tocar num ponto importante: o do aprendizado da antropologia. Se os textos teóricos, geralmente divulgados em artigos de revistas especializadas - e mais raramente em livros -, representam uma indiscutível contribuição para a formação do jovem aprendiz tanto quanto exercem desafios variados ao profissional da disciplina, é nas monografias, produto de pesquisas etnográficas cuidadosas, que se forma o bom pesquisador. São as chamadas monografias exemplares com cuja leitura - você sabe muito bem - todos nós aprendemos a antropologia. Ora, se não todas, pelo menos as mais exemplares foram editadas com a preocupação de situar imageticamente o povo, objeto de investigação. Embora não tenha nenhuma pretensão de ter produzido textos modelares, vali-me das fotos sempre onde e quando pude, procurando seguir certamente o padrão ensinado pelas melhores monografias, clássicas e modernas.

João Martinho de Mendonça: Queria agora pedir ao senhor para falar um pouco mais especificamente do uso da fotografia no $O$ índio e o mundo dos brancos, tanto na pequisa de campo como no livro.

Etienne Samain: Por que fez fotografias, por que julgou na época importante introduzir num texto - finalmente muito teórico e reflexivo documentos que, por vezes, são relacionados ao mundo dos Tükúna (e ao seu texto) de maneira apenas lateral, oblíqua, tangencial?

Roberto Cardoso de Oliveira: A explicação mais plausível é a mais pedestre possível: como disse, segui um padrão. Havia um hábito de sempre o antropólogo ilustrar o seu trabalho, então a questão era muito mais a de ilustrar. A antropologia que se fazia no exterior e que todos nós fazíamos no Brasil tinha a foto, de um lado, como uma ilustração em termos de livro, istóé, de texto publicável; por outro lado, provavelmente no subconsciente do pesquisador, havia esse outro aspecto que hoje se observa melhor e 
que seria a legitimação do pesquisador. O tal "estive lá", tão discutido na chamada antropologia pós-moderna. Claro que não se pensava isso na época, mas esse padrão foi criado muito como uma forma de legitimar. "Realmente eu estive lá, eu estive entre os selvagens", isso vem desde Malinowski . Então isso ficou como uma receita.

Agora como você transforma a linguagem das fotos, a linguagem das imagens, numa linguagem etnográfica também? Porque até então era uma linguagem muito mais artística, entra muito como ilustração, às vezes inspiradas - as fotos - por princípios estéticos; entra como arte, portanto nem sempre como documentação. Evidentemente que não quero generalizar, falo muito por mim! Até onde isso pode ser generalizado? Ao que parece, a documentação fotográfica "fala" quando o antropólogo fala por ela, relacionando-a explicitamente com alguma coisa, como no texto-legenda. O que é que se põe no texto-legenda? Diz-se quemé quem, dá a data e dá o autor da fotografia, é o que geralmente acontece. Pareceme que a foto começa a falar por si quando o texto se inspira no que denominamos nessas últimas décadas antropologia visual. Seguramente, uma nova atitude!

Etienne Samain: Prolongando seu raciocínio, gostaria de lhe submeter uma reflexão, que será, também, uma interrogação. Escrevi um artigo precisamente sobre o uso que Malinowski faz da fotografia, nas suas três monografias dedicadas aos nativos das ilhas Trobriandeses (onde permaneceu de 1914 a 1918). Interessante observar que desde a primeira, $O s$ argonautas do Pacífico Ocidental (1922), depois A vida sexual dos selvagens (1929) e, finalmente, Os jardins de coral e suas mágicas (1935), nestas monografias, Malinowski faz um uso constante e cada vez maior de fotografias. Um uso, aliás, que poderíamos qualificar de impressionante (75 fotografias em Os argonautas, $92 \mathrm{em}$ A vida sexual e 116 em $O$ s jardins), tendo-se em mente o fato de que estamos no começo do século, que Malinowski não é um hábil fotógrafo e mais... que não gosta de fazer fotografias. Resta que o pai do funcionalismo, apesar dos pesares, 
fez centenas de fotografias que inseriu, com grande cuidado e precisão, no interior de seus textos. Sem entrar nos detalhes dos usos da fotografia a serviço da concretização de sua visão (e projeto) funcionalista da sociedade que estudava, volto à minha reflexão, interrogação ou, talvez, simples hipótese de trabalho. Como explicar o crescente desuso da fotografia no campo da antropologia após Malinowski? Deve haver uma explicação, parcial pelo menos, assim penso, no distanciamento crescente das teorias antropológicas (que sucederam ao projeto funcionalista de Malinowski), com relação à concretude palpável e visível das sociedades estudadas.

Se esta hipótese for exata, entender-se-á por que, passando do funcionalismo de Malinowski (as sociedades "funcionam", são redes de relações e de concatenações presentes entre os elementos e fatos, visíveis e palpáveis, dos grupos sociais) ao conceito de "estrutura" - noção já abstrata nas obras de E. E. Evans Pritchard (que oferece um bloco de diversões fotograficas "exóticas" do tipo: "Moça no Kraal", mostrandonos uma esbelta criatura Nuer) e que perderá toda visibilidade direta nos trabalhos do pai do estruturalismo, Claude Lévi-Strauss (que, fora as fotografias inseridas no seu Tristes trópicos, somente aceitará abrir o baú de seu riquíssimo tesouro fotográfico, de suas "saudades" de São Paulo e do Brasil, no entardecer de sua vida) - a fotografia devia desertar o campo específico da antropologia social? Para dizer as coisas de maneira mais crua: dentro do projeto teórico estruturalista, as fotografias nãoserviam para mais nada! Lévi-Strauss é muito claro: "Sou etnógrafo e não fotógrafo. A cada um sua especialidade!".

Mas tenho que ir mais adiante. O que acabei de evocar significa que a constituição de uma antropologia visual, qualquer que seja, nunca deverá minimizar o impacto, os condicionamentos, os imperativos, que todo projeto teórico antropológico crava na própria visualidade do pesquisador.

Será que poderia ser uma hipótese explicativa do desaparecimento progressivo, do começo do século até os anos 60 , da imagem no campo da antropologia? 
Roberto Cardoso de Oliveira: Isso coloca questões interessantes para a gente refletir, não é? Vamos ver no caso de Lévi-Strauss. É patente como ele separa o exercício da antropologia estrutural como uma verdadeira ciência, não ciência natural, uma vez que ele se fundamenta na lingüística, uma ciência humana; mas há toda uma preocupação em gerar proposições, portanto uma disciplina para ele nomológica. Eque, como você disse muito bem, ele trabalha num plano muito mais abstrato. Basta ver As estruturas elementares do parentesco, inclusive o tratamento matemático que ele dá através da assistência de André Weil, este matemático que colabora com ele, num esforço de valer-se de uma matemática qualitativa para dar conta de relações de aliança, trocas etc, isso tudo resulta em um trabalho marcante na literatura da nossa disciplina, um verdadeiro clássico moderno da teoria antropológica.

Mas ele se preserva realmente do uso de uma outra linguagem, que ele vai se permitir utilizar na linguagem solta do Tristes trópicos. E tanto isso parece ser verdadeiro que, com Tristes trópicos, ele vai se revelar o talentoso écrivain que efetivamente é, sem prejuízo de sua incrível competência de teórico. Porém foi graças a esse livro que ele entra no Collège de France. Nele identificamos dois discursos: o discurso cientificista do estruturalismo, que ele faz questão que seja científico, e o discurso do seu...

\section{Etienne Samain: Filosófico...}

Roberto Cardoso de Oliveira: É... Meio filosófico... Talvez mais literário, quem sabe ressucistador da velha crônica dos viajantes estrangeiros. Talvez ele não admitisse sem remorsos falar em filosófico, porque tinha como profissão de fé se negar à filosofia. Conversando com ele em 1981, coloquei estes problemas e ele achava que eu era muito mais filósofo do que ele, porque eu era muito mais fiel a la pensée philosophique. Ele brigava com isso, mas evidentemente era uma forma dele se exprimir, porque ele tinha uma boa base em filosofia. Sua formação filosófica talvez não fosse muito diferente daquela que nós, estudantes de filosofia no Brasil em 
princípios dos anos 50, obtivemos na Faculdade de Filosofia, Ciências e Letras da USP, onde, aliás - e você sabe muito bem - o Professor LéviStrauss ensinou. Muitos dos formados em filosofia na França e, é verdade, poucos de nós no Brasil, viemos da filosofia... e fomos para as ciências sociais. Não sei dos jovens, mas dos velhos só me ocorre, além de mim, o falecido Professor Egon Schaden.

Mas voltemos ao que interessa. Lévi-Strauss é alguém que aceitou pagar o preço de não se dedicar à atividade filosófica para se tornar um cientista, ou um savant como se auto-classificaria em princípios do século, tal como tentou fazer Lévy-Bruhl. Talvez tenha sido o abandono da filosofia o que lhe custou para se tornar o antropólogo eminente que é, criador de um novo paradigma para a antropologia social, muito aproveitado por disciplinas adjacentes... Aí nós podíamos discutir muito, mostrar outros caminhos, de outros autores, como o próprio Lévy-Bruhl, que nunca deixou de ser filósofo, por mais que ele quisesse ser o cientista que se programou ser; um tema, aliás, sobre o qual escrevi naquele meu livro, Razão e afetividade. O pensamento de Lucien Lévy-Bruhl, que me permito supor seja de seu conhecimento.

Etienne Saimain: Sim, eu tenho, claro...

Roberto Cardoso de Oliveira: Porém, o que acho surpreendente é verificar a existência de antropólogos que já nos anos 50 , quer dizer, nos anos 40 e mesmo antes, produziram trabalhos interessantíssimos no campo das imagens; eu me lembro de Margaret Mead, e de seu terceiro marido, também companheiro de pesquisa, Gregory Bateson, autores de um pioneiríssimo livro de 1942, Balinese Character: A Photographic Analysis; além de Rhoda Metraux, com quem ela escreveria um manual sobre teoria e prática no estudo de culturas à distância. Penso que Margaret Mead tenha sido pioneira em mostrar a importância da linguagem da imagem e em querer o tal do estudo à distância. Pergunto-me como isso não teve repercussão, não teve uma continuidade? Como ela não criou uma "escola" na antropologia visual? 
Revista de Antropologia, São Paulo, USP, 2000, v. 43 nº 1.

Tentaria uma interpretação - não sei se seria a melhor, mas pelo menos serviria como hipótese razoável - segundo a qual o contexto em que Margaret Mead usou a imagem foi um contexto eminentemente político, vinculado aos interesses do Departamento de Estado norte-americano e relacionado com a Segunda Guerra Mundial. O esforço em entender, por exemplo, países que você não podia pesquisar diretamente a não ser por imagens. Foi o caso da União Soviética, do Japão imperialista, entre outros, países de impossível acesso pela investigação etnográfica no período.

Então tenho a impressão que na própria história da antropologia isso ficou muito marcado como uma certa applied anthropology de pouco prestígio no meio universitário norte-americano. Esse desprestígio resultou numa sinalização negativa, um sinal menos, na tradição da antropologia estadunidense, complicando-se na guerra fria e depois dela com as políticas pouco moralmente corretas do departamento de estado. A rigor, essa antropologia aplicada já trazia o ranço do colonialismo inglês, com o qual os antropólogos britânicos conviveram com maior ou menor consciência política... Esses são fatos que deixaram marcas na consciência histórica da disciplina, gerando, pelo menos nas mentes mais abertas do chamado primeiro mundo, um expressivo sentimento de culpa... que tentam expiar de várias maneiras... Não existe a associação - certamente exagerada da antropologia com o colonialismo? E entre nós, no Brasil, a associação entre indigenismo e colonialismo interno? Mas isso não é assunto para a nossa entrevista, iria sobrecarregá-la.

Mas voltando à possível influência atual de Margaret Mead e seu interessantíssimo Balinese Character, sua possível influência estaria sendo sentida ainda hoje, talvez retomada nesses últimos dez anos ou mais? Não sei...

Etienne Samain: Diria desde os anos $60 . .$. o problema é que Balinese Character é, muitas vezes, citado mas, até hoje, foi realmente pouco estudado... Felizmente, vamos ter em breve alguns trabalhos de qualidade sobre esse "monumento" da antropologia visual... penso no trabalho que desenvolve atualmente um orientando meu, André Alvés, no meio dos 
Etienne Samain e João M. De Mendonça. Diálogos com Roberto Cardoso de Oliveira

caranguejeiros da ilha de Vitória, seguindo os padrões metodológicos de Balinese Character... outros vão aparecer...

Roberto Cardoso de Oliveira: Isso é ótimo! Vejo aí, nesse vigor de agora da antropologia visual, a participação de colegas que estão em departamentos de antropologia como a nossa colega da Unicamp - que você mesmo há pouco mencionou -, a professora Bela-Bianco. Creio que ela trabalha em antropologia visual pelo menos há seis anos. E você trabalha nisso já há algum tempo não é? Aliás tenho enorme interesse em conhecer o estado da arte da antropologia visual no Brasil, alguém precisa escrever isso.

Etienne Samain: Mas isso está saindo...

Roberto Cardoso de Oliveira: Pois é, precisa escrever isso: qual o estado da arte na antropologia visual. Quer dizer, você tem pinceladas ali, você tem informações aqui, mas isso é importante fazer.

Etienne Samain: Irei lhe passar isso.

Roberto Cardoso de Oliveira: Então eu espero, quero ver.

João Martinho de Mendonça: Examinamos também outras representações imagéticas dos Tükúna que pudemos encontrar na perspectiva da via acadêmica. Refiro-me ao trabalho do Mal. Rondon, de Curt Nimuendajú e de João Pacheco de Oliveira Filho. Poderíamos incluir também um álbum fotográfico intitulado Amazônia, publicação italiana de 1994 que traz pequenos textos explicativos e até mesmo uma fotografia de uma jovem "moça nova" de nome Edineusa Araújo publicada na Folha de S.Paulo em 21 de outubro de 1996. Pode-se notar em todas essas representações imagéticas nuanças significativas de acordo com o contexto de produção de cada uma delas. No entanto, ao menos ao nível temático, 
o que se vê é uma concentração em torno de aspectos da cultura material, particularmente nos trabalhos de Rondon e de Nimuendajú na primeira metade do século, bem como sobre aspectos do ritual da "moça nova".

Em seu artigo de 1996 "Olhar, ouvir, escrever”, especificamente na seção dedicada ao "olhar", o senhor fala sobre a domesticação teórica do mesmo e para isto usa a imagem da refração: "Seja qual for esse objeto, ele não escapa de ser apreendido pelo esquema conceitual da disciplina formadora de nossa maneira de ver a realidade.". Creio que poderíamos estender esta imagem da refração às representações imagéticas que enumerei acima acrescentando que o procedimento fotográfico opera um corte no tempo e no espaço, portanto na realidade que está sendo vivenciada.

Sem aprofundar ainda esta questão eu diria que, de um modo geral, podemos configurar nestas imagens uma certa maneira de ver a realidade, caracterizada pela afirmação de uma superioridade tecnológica e moral, numa espécie de processo irreversível e impessoal (em que a experiência do outro é transformada em objeto de curiosidade dentro de uma escala evolutiva concebida mundialmente).

Como o senhor pensaria a possibilidade de transformar essa imagem generalizada que foi construída, isto no sentido de ampliar nossa maneira de ver a realidade, enxergando o outro talvez dentro de categorias mais familiares e contribuindo à redução desta assimetria moral já tão bem estabelecida ao menos no campo do imaginário?

Roberto Cardoso de Oliveira: Entendo que o imaginário é domesticado pelo paradigma teórico que orienta o olhar do observador. Daí porque um paradigma evolucionista, hoje anacrônico, pois vigente há quase um século atrás, foi responsável pela compreensão das culturas nos termos de uma escala evolutiva, de inspiração biológica, a par de um desconhecimento gritante sobre o funcionamento das sociedades ditas primitivas. Mas isso já era... O imaginário estará sempre contaminado não só por ideologias, mas também pela natureza das disciplinas. Se tomarmos, por 
Etienne Samain e João M. de Mendonça. Diálogos com Roberto Cardoso de Oliveira

exemplo, o olhar de um folclorista - e sem nenhum menosprezo pelo folclore, como disciplina -, veremos que ele tenderá a folclorizar-se assim posso me exprimir - a realidade observada (privilegiando o exótico ou seu caráter de sobrevivência etc). E assim por diante... Quanto à redução da assimetria moral de que você fala, como o de alguém não mais ser induzido a ver o Outro como inferior (se é que entendi sua questão), acredito que essa assimetria tende a se reduzir, sobretudo na mídia, em decorrência da contribuição da própria antropologia em sua luta persistente contra o preconceito étnico e racial, em defesa da diferença, tanto quanto na participação dos antropólogos na defesa das minorias sociais em geral. É quando o discurso científico desliza legitimamente para o discurso político, em seu sentido de democratização das relações humanas, e, sobretudo, segundo meu ponto de vista, para o discurso moral. O que não significa que nas regiões onde existem índios ou, se quiser, nas áreas de fricção interétnica, ocorra a mesma tendência; contar, nessas regiões, com qualquer tendência à simetria isso seria utópico.

João Martinho de Mendonça: Temos no seu livro de 1976, Identidade, etnia e estrutura social, um quadro representando a matriz dos sistemas interétnicos. No livro de 1988, Sobre o pensamento antropológico, encontramos um quadro semelhante, desta vez representando uma matriz disciplinar da antropologia. Parece evidente que a visualização desempenha um papel bastante importante para o entendimento se pensarmos com este tipo de estrutura abstrata. Poderíamos falar também de outros esquemas (genealógicos etc.) que são a expressão de idéias que se fazem entender melhor através da visualização.

Gostaria de apontar, para esta questão, as seguintes passagens de $O$ índio e o mundo dos brancos: "O caboclo, na área tomada para investigação, é o Tükúna transfigurado pelo contato com o branco. (...) O caboclo é, assim, o Tükúna vendo-se a si mesmo com os olhos do branco (...) Fracionada sua personalidade em duas, ela bem retrata a ambiguiidade de sua situação total, que pretendemos descrever, tomando flashes de 
suas configurações mais significativas" (1994: 117, grifos dos entrevistadores). Aqui o discurso escrito parece mesmo dialogar com procedimentos visuais e até mesmo fotográficos.

O ato de olhar não estaria portanto, talvez de um modo peculiar, bastante intrínseco ao ato de pensar, um pouco no sentido talvez que o senhor considera $\mathrm{o}$ ato de escrever? Lembro que o senhor disse anteriormente que "pensamos escrevendo", não poderíamos então dizer também que, de uma outra maneira, "pensamos visualizando"?

Roberto Cardoso de Oliveira: Para os que vêem, os que enxergam, eu tenderia a concordar. Nesse sentido, talvez a psicologia da inteligência possa nos ensinar alguma coisa. Ou a própria filosofia, pois para um filósofo como Wittgenstein não era fundamental para a linguagem a sua própria figurabilidade? Mas vamos pensar como etnólogos, imaginando um cego de nascença como pesquisador. É fato que ele não teria condições de observação, literalmente falando. Contudo, pode ler em braile, ouvir, tocar o Outro, tocar as coisas sensíveis etc. Pode trabalhar - e bem - em etnohistória, por exemplo, socorrendo-se de leitores para ajudá-lo. Quem sabe até ser membro de uma equipe de pesquisa de campo, na qual poderia contar com a ajuda de seus colegas. Conheci um sociólogo da USP, o professor Azis Simão, já falecido que, apesar de cego, fez uma bonita carreira docente e de pesquisador, sendo autor de livros e artigos ( sempre contando também com a ajuda de sua mulher que certamente era sua leitora preferida). São coisas a pensar! E por essa razão é que ainda considero o escrever como o ato verdadeiramente fundante na elaboração de um conhecimento que se expressa, em sua forma mais acabada, no discurso escrito.

Quanto ao meu uso, talvez excessivo, de esquemas e diagramas, provavelmente se explique, de um lado, pelo meu próprio idioleto mental; por outro lado, devido à minha longa exposição à influência do pensamento estruturalista através do uso de modelos abstratos. O que posso dizer agora é que sua pergunta me leva a pensar... é uma boa questão. 
João Martinho de Mendonça: Acho que é também uma tarefa tentar entender como a maneira de pensar e conceber a fotografia vai se transformando. Será que hoje a fotografia talvez se desligou daquele mesmo objetivismo de que o senhor falou no início da entrevista, pois que a fotografia também estava relacionada a um olhar objetivo, que vem da antropometria, o olhar neutro...?

Roberto Cardoso de Oliveira: Seria a chamada neutralidade. A foto é boa porque é neutra, não é mais do que uma ficção. Conforme o ângulo que você dá na fotografia ela não é mais neutra, quer dizer: a foto tem também o seu ponto de vista, que é o ponto de vista de quem está atrás da foto.

Etienne Samain: Por isso eu acho que seria interessante pensar também no ato de escrever e nas suas implicações hermenêuticas. Escrever significa representar a realidade por meio do suporte da escrita, o que o antropólogo faz interpretando, sempre, esta realidade... como também o fotógrafo... fotografando, usando de um outro suporte, mas sem que pudesse, portanto, desaparecer, "sumir" enquanto sujeito cognoscente, isto é, interpretante... ele também... O que me provoca, então, nessa aliança que temos que reconstruir entre a escrita e a visualidade, não é apenas a questão das singularidades dos suportes, mas a maneira com que, através deles, estamos engajados, condicionados e convidados num ato conjunto - distinto e complementar - de interpretação e da compreensão da realidade humana.

Roberto Cardoso de Oliveira: O fotógrafo interpreta pelo ângulo, pela distância. A distância vai mostrar até onde a pessoa está, mesmo você usando lentes, zoom e outras coisas com que você aproxima a imagem . Mas de qualquer maneira há de se conhecer minimamente o métier do fotógrafo e poder fazer uma leitura do ponto de vista técnico.

Etienne Samain: Com certeza. 
Revista de Antropologia, São Paulo, USP, 2000, v. 43 nº 1.

Roberto Cardoso de Oliveira: Isso me parece ser uma tarefa de vocês, antropólogos visuais, que poderiam contribuir para uma melhor compreensão da articulação do discurso textual com o imagético, daí tirando ensinamentos úteis para todos nós.

João Martinho de Mendonça: Esboçamos uma comparação entre o olhar fotográfico contido nas fotografias do livro de Curt Nimuendajú e aquelas que estão em $O$ índio e o mundo dos brancos. Buscando empreender uma análise técnica mais aprofundada das imagens, elegemos algumas fotografias representativas da festa da "moça nova" em ambos os livros. Vimos daí a configuração de dois olhares fotográficos diversos. Elaborei então a hipótese de que as diferenças estariam também refletindo um pouco da trajetória e do pensamento cristalizados em ambos os livros.

Resumidamente diria que o olhar de Nimuendajú procura fixar sob um ângulo específico (de uma descrição realista) no sentido de registrar uma totalidade cultural em desaparecimento. Já o olhar das fotografias associadas ao $O$ índio e o mundo dos brancos parece estar buscando pontos de vista diversos e variados, aproximando-se e afastando-se, no sentido de procurar construir uma reflexão sobre uma situação dinâmica. Diria que aqui há um processo de investigação do olhar, ele se impõe numa interação, é elaborado durante o acontecimento. No outro caso tem-se um método de olhar fixo, talvez previamente elaborado e aplicado regularmente, mesmo com a ostensiva participação e colaboração dos fotografados.

Caso a hipótese seja pertinente, de que o ponto de vista do fotógrafo interpretado tecnicamente reflita aspectos do pensamento do autor, não teríamos aqui também um índice de que ao olhar fotograficamente estaríamos exprimindo idéias? Talvez aqui a imagem da refração possa adquirir maior amplitude.

Roberto Cardoso de Oliveira: É uma questão a pensar mais maduramente. E um tema bem ao gosto da antropologia visual, não é? Comentaria apenas que, no caso de meu livro, há dois autores das fotos: eu, com 
mais fotografias no livro, e Maurício Vinhas de Queiroz, meu companheiro de viagem. Não poderia precisar agora quais as minhas e quais as dele, uma vez que elas se dispersam nas diversas edições do livro. Sobre as minhas posso falar e dizer que efetivamente teriam um objetivo mais sociológico, como o de retratar posições sociais, atividades, comportamentos associativos e por aí vai... Já nas do Maurício, creio que preponderava mais o fator artístico, fotógrafo profissional que era.

João Martinho de Mendonça: Tínhamos como hipótese inicial nesta pesquisa a idéia de que as fotografias tomadas durante a pesquisa de campo entre os Tükúna poderiam complementar ou talvez ilustrar também o pensamento desenvolvido em $O$ índio e o mundo dos brancos, mostrando alguns aspectos da situação de fricção interétnica levantada na região. Como exemplo poderíamos pensar nas fotografias posadas da família de Antonio Roberto Aires de Almeida, nas fotos de famílias de regionais "neobrasileiros" ou nas imagens da polícia colombiana encontrada nas divisas do igarapé, em contraposição talvez às imagens dos Tükúna na festa de "moça nova".

Num sentido mais reflexivo poderíamos pensar também que as fotografias tomadas pelo senhor e por Maurício Vinhas de Queirós teriam constituído uma espécie de índice da situação João Martinho de Mendonçautensílios modernos, era como a "natureza morta da aculturação". Com minhas fotos eu procurava registrar um pouco do processo de contato interétnico que resultasse num quadro pelo menos mais "vivo" que o de Baldus... Porém, se você pensa em ligar as fotos ao texto, há de dissociar o discurso textual presente no livro das imagens produzidas pelo Maurício, pois elas foram feitas com sua absoluta autonomia de fotógrafo. Lembro-me de que todas as vezes que eu the pedia a fotografar algo, uma ou outra cena, ele me dizia que não estava inspirado. Ele era o artista.

Etienne Samain: Agora estou me perguntando - aliás isso foi a temática de um pós-doutorado, que fiz na França em 1991-92, mas que, confesso, 
não consegui até hoje fechar... - : será que podemos falar de um "pensamento visual fotográfico"? Penso, agora, que, além de complexa, a questão foi mal encaminhada. Diria hoje: será que existe um pensamento sensorial (de nossos sentidos e de suas inter-relações, patentes em termos da neurobiologia cerebral), presente no ser humano, ao lado de um pensamento lógico (melhor alimentado e nutrido pelas vias da fala e da escrita)? Levanto uma interrogação que, com certeza, mereceria um outro longo momento de discussão...

Uma coisa é certa: devo essas interrogações a Claude Lévi-Strauss e ao seu $O$ pensamento selvagem (também, devo muito a Jack Goody e ao seu A domesticação do pensamento selvagem). É tão verdadeiro que, em janeiro de 1992, quis submeter a proposta de um "pensamento visual fotográfico" à própria apreciação de Lévi-Strauss. Com rara cortesia, recebeu-me na pequena sala que ocupa no Collège de France e me disse: "Oh, meu caro colega, acho esse problema muito interessante, mas não para antropólogos". Até hoje, me pergunto: "por que não?" e, tanto mais que, na época, Lévi-Strauss me dizia: "aliás, atualmente estou redigindo um novo livro (publicado sob o título Écouter, Regarder, Lire )"...

Roberto Cardoso de Oliveira: Nesse livro ele fez antropologia estética... Mas quanto ao cerne de sua questão, acrescentaria que se não cabe ao antropólogo tout court enfrentá-la, cabe ao antropólogo visual, associado a colegas psicólogos e a outros profissionais conjugados. É uma área de fronteira interdisciplinar que a questão nos convida a entrar...

Etienne Samain: ... Bom, isso no final de sua vida, dizendo-me: "atualmente estou diante de um problema de compreensão das cores e, caro colega, vou lhe dizer: pedi a outros colegas para me fornecerem artigos e livros sobre o assunto, li tudo e não entendi nada!" ( risos ). $\mathrm{O}$ título deste livro (Écouter, Regarder, Lire) me parece particularmente interessante por parte deste antropólogo, sobretudo na medida em que suscitou, por parte do senhor, um outro despertar: seu recente artigo "O 
Etienne Samain e João M. de Mendonça. Diálogos com Roberto Cardoso de Oliveira

trabalho do antropólogo: olhar, ouvir , escrever"... Gostaria de voltar, um dia, para isso.

Existe, ainda, um outro autor, polêmico tanto como instigante, o Dan Sperber que acaba de publicar um novo livro intitulado La contagion des idées (1996)...

Roberto Cardoso de Oliveira: É, eu não tenho tanto entusiasmo pelo Dan Sperber, mas posso mudar de idéia lendo esse seu novo livro ( $O$ fotográfico)... Talvez porque considere que a antropologia francesa ainda não encontrou teóricos do porte de Lévi-Strauss e Louis Dumont. Mas por falar neles, lembro-me de haver estado com Dumont apenas uma vez quando o conheci em Nova Iorque, durante uma reunião da American Anthropological Association e, depois, o revi em Harvard, numa das vezes em que estive lá, e ele estava ministrando conferências. Ele estava elaborando seu livro Homo Aequalis e, lembro-me, por nossa conversa, de que já pensava em escrever sobre o pensamento alemão, especialmente sobre Herder e Fichte (lembro-me disso porque eram autores também de meu interesse). Quanto a Lévi-Strauss, eu, infelizmente, convivi muito pouco com ele, em 1981, quando fiquei três meses em Paris associado a Maison des Sciences de l'Homme. Estava trabalhando com os inéditos de Marcel Mauss, nos arquivos do Groupe d'études durkheimiènes. Pude então visitá-lo no Collège de France, em seu gabinete de trabalho. Nessa ocasião me deu uma notícia que me deixou muito satisfeito: disse-me que em seus seminários de Mardi, destinado ao tema Identidade, havia dado para discussão o meu livro Identidade, etnia e estrutura social, publicado cinco anos antes e provavelmente exposto por alguém que lia português, porque a edição castelhana só sairia em 1992. Durante o agradável encontro, comentando seus próprios trabalhos, disse a mim que não ia escrever mais, que já estava velho e... em 1981! - depois escreveria ainda vários livros, não é? ( risos ) Não é gozado?

Etienne Samain: Sim, eu acho que... ele faz de propósito. 
Revista de Antropologia, São Paulo, USP, 2000, v. 43 nº 1.

Roberto Cardoso de Oliveira: É, era um charme, mas já devia estar doente. Parece que estava com mal de parkinson. Suas mãos tremiam quando escrevia. Eu não sei como ele está agora, você o viu quando?

Etienne Samain: Em 1992, começo de 92, até que ele queria carregar minha mala, uma pesada mala que levava, pura gentileza dele... o problema é que não queria matá-lo...

Roberto Cardoso de Oliveira: Pois é, mas já passaram seis anos...

João Martinho de Mendonça: Aproveitando o ensejo, sobre a dimensão autoral, gostaria de colocar uma questão. Clifford Geertz em Works and Lives: anthropologist as author fala sobre os perigos de se considerar a vocação antropológica como literária, reproduzo aqui um deles: "O empreendimento também pode ser considerado pura sedução verbal: artifício retórico inventado para fazer circularem bens intelectuais num mercado competitivo". Tomarei sobre isto a seguinte passagem de Adorno em Minima moralia: "A circunstância de que os intelectuais se relacionam quase que só com intelectuais não deveria induzi-los a considerar seus pares como mais infames que o resto da humanidade. Pois eles tomam conhecimento uns dos outros, sem exceção, na mais vergonhosa e indigna das situações, a de postulantes em concorrência, e por isso exibem uns aos outros, quase compulsivamente, as facetas mais abomináveis". Como, dentro da perspectiva antropológica, o senhor responderia a este tipo de inquietação?

Roberto Cardoso de Oliveira: Vejo isso como uma maneira bem adorniana e pessimista de diagnosticar as coisas. Entendo que há duas faces da "comunidade de comunicação" (expressão essa apeliana, do filósofo Karl-Otto Apel): uma saudável, quando voltada para o exercício honesto e bem intencionado da argumentação interpares, empenhada em alcançar consenso; a outra face, perversa, quando essa comunidade de comunicação interpares se orienta para aquilo que um autor, como Bourdieu, chama de 
Etienne Samain e João M. De Mendonça. Diálogos com Roberto Cardoso de Oliveira

"clube de elogios recíprocos". Penso que tais elogios são mais funestos do que a crítica raivosa...

João Martinho de Mendonça: Professor, agora eu tenho algumas perguntas que, acho que depois de tudo isso, ficam até um pouco mais chatas. São questões sobre que máquina foi usada, o que o levou a doar o material para o acervo e se ainda pensa em retornar, em voltar a olhar esse material e fazer alguma coisa...?

Roberto Cardoso de Oliveira: Sobre a máquina que usei, que me lembro e, acho que foi uma Rolley-flex, acho que eu trabalhava no alto Solimões com uma Rolley-Flex. Já, anteriormente, na etnografia dos índios Terêna, lembro-me de ter usado uma Zeitz, bem pequena, propriedade do Museu do Índio.

Evidentemente que doei esse material aos arquivos, tanto os relativos aos Tükúna quanto aqueles obtidos junto aos Terêna. Eles estão no Edgard Leuenroth por causa das dificuldades que Mariza Corrêa tinha em conservar em bom estado todo o material por ela colhido no âmbito do projeto de estudo sobre a Antropologia Brasileira. Ela tinha que guardar isso em algum lugar; com as grandes dificuldades que se tinha na Unicamp, decidiu-se que era melhor juntar numa sessão do Arquivo.

Durante muitos anos esse material ficou numa sala do IFCH, que tinha meu nome na porta... No começo ela queria identificar a sala como "Arquivo RCO"; eu fui contra, e falei: "Não, você põe 'Arquivo Histórico da Antropologia Brasileira', porque não tinha só os meus dados, tinha dados do Pierson, do Emílio Willems". Aliás, sobre ambos ela chegou a publicar um interessante volume, em 1987, intitulado História da antropologia no Brasil (1930-1960): testemunhos de Emilio Willens e Donald Pierson, que seria o primeiro de uma série sobre a história da disciplina entre nós.

E só nos cabe esperar que seu empreendimento continue, já que ela conseguiu reunir vários depoimentos: do David Maybury-Lewis, do Roberto Da Matta, do Luiz de Castro Faria e de alguns outros mais. 
Sobre o depoimento do Castro vale uma pequena história. Colaborei em sua entrevista porque Mariza achava que Castro Faria era uma pessoa muito difícil, não era muito dado a entrevistas, muito menos para falar de si. Então ela me pediu: "Roberto, vê se você vai comigo". Eu, como estava no Rio, numa das minhas viagens, pois eu ia mensalmente ao Rio de Janeiro, falei: "Mariza eu vou para o Rio agora, se quiser você vai também e nós faremos a entrevista".

Fomos eu, ela e mais sua auxiliar, encarregada de gravar e fotografar a entrevista, registrando tudo. Fui apenas o mediador. Então quando o Castro falou: "Eu não vou falar sobre...", logo interferi: "Ah, fala Castro, você tem que falar, você tem o que dizer". Dessa maneira eu o estimulava para a entrevista conduzida inteiramente pela Mariza e que acabou resultando num excelente material para a pesquisa.

Etienne Samain: O senhor viu lá em Vitória, na $21^{\mathrm{a}}$ Reunião da ABA em 1998, a sua apresentação? Lindíssima! Sim, mas ao saber sobre essa primeira história e tendo visto o depoimento que ele deu, os slides que ele apresentou, amigos que conseguiram abrir o acervo dele, tudo isso é para mim uma lição de antropologia.

Roberto Cardoso de Oliveira: Sim, mas todo esse material não é de agora. O Castro vem reunindo fotos e documentos em seu acervo há anos, razão - pelo menos uma das razões - pela qual ele foi entrevistado pela Mariza! Ele é a nossa melhor memória da disciplina. Mas é muito avesso a dar depoimentos.

Etienne Samain: Mas desde este primeiro contato, então, ele amadureceu a idéia...

Roberto Cardoso de Oliveira:Pode ser. Porque agora o Castro tem um entourage de ex-alunos no Museu Nacional ena Faculdade Fluminense, que o amparam e estimulam. Inclusive fizeram esse livro porque o Castro publicou relativamente pouco. Mas o que publicou foi sempre de boa 
Etienne Samain e João M. De Mendonça. Diálogos com Roberto Cardoso de Oliveira

qualidade refletindo os diferentes momentos de sua antropologia. Castro Faria foi treinado para ser um arqueólogo, inicialmente antropólogo físico e, depois, transformou-se em antropólogo social, quer dizer, ele é o mais próximo que nós temos da idéia "Boasiana" de antropologia no Brasil, nãoé?

E o Castro é muito auto-crítico... Mas se ele tinha dificuldade em produzir por excesso de autocrítica, por outro lado sempre tinha projetos, sonhos. Se escrevesse um dia sobre o sonho na antropologia, eu tomaria o Castro como "personagem conceitual". Ele é excepcionalmente inteligente e realmente é um sonhador, porque sempre tem dois, três, quatro livros arquitetados, prontos para serem escritos... Por isso foi muito bom que, nessa reunião da $\mathrm{ABA}$, tenha saído um primeiro volume de sua obra; vão sair outros, estando prevista uma trilogia, de modo que todos os trabalhos que ele escreveu, dispersos em diferentes publicações, vão estar organizados lá, e disponíveis para as novas gerações. Acho que foi uma boa iniciativa de seus ex-alunos, hoje seus colegas.

Mas, retomando a pergunta do João Mendonça sobre a doação do meu arquivo para a Unicamp - que acabei não respondendo -, diria que foi uma casualidade. Eu tinha um material muito grande de documentos muito variados relativos à minha trajetória profissional, com passagem por diferentes instituições, como o Museu do Índio, o Museu Nacional, a Universidade de Brasília, além de alguns colegiados de órgãos nacionais e internacionais, conselhos de revistas científicas, etc, etc. Quando saí de Brasília em 1985, em janeiro, ou melhor, em dezembro de 1984, fui para a Unicamp e deixei na sala que tinha aqui um material muito grande de arquivos, documentos etc... Eu sempre guardava as coisas, não jogava fora, eu mesmo classificava em pastas devidamente identificadas. Inclusive, tinha a minha correspondência desde 1955 ou 1956 devidamente arquivada.

Então tinha todas essas coisas e eu não ia estar carregando nas costas, mudando-me para Campinas. Tudo isso ficou numa sala de uma colega, a professora Alcida Rita Ramos, e fiquei preocupado porque ela estava com todos os arquivos, sem poder usar o espaço com seu próprio material.

Falando com a Mariza, ela teve a idéia do programa de história da antropologia ficar com esse material. Eu faria uma doação formal, o que 
Revista de Antropologia, São Paulo, USP, 2000, v. 43 nº 1.

foi feito. E a Unicamp assumiu o encargo de mandar buscá-lo em Brasília. Então vieram de lá 13 caixas desse tamanho, 13 caixas... (indica com um gesto, risos). Então ela viu, não sei se ficou surpresa ou não, e pediu uma sala grande para colocar o meu acervo.

Atualmente já aumentou bastante, pois faz mais de uma década e nesses anos estou sempre mandando. Cada ano você tem uma correspondência, uma pasta que começa fininha e fica assim... (gesto). Eu sempre guardo comigo a correspondência por cinco anos, em média, mas agora constato que já preciso mandar várias pastas. Eu já devia ter ficado somente com as de 1998, 97, 96, 95 e 94. Quer dizer, significa que 90, 91, 92, 93 eu já devia ter enviado, porque ainda estão comigo. Preciso mandar para ela. Mas o que eu quero dizer é que doei também como uma forma de colaborar com o projeto sobre História da Antropologia no Brasil, e uma maneira de verificar se o que tenho pode servir, eventualmente, como testemunho da antropologia vivida por mim durante um longo período.

Trabalho em antropologia desde 1954. E desde 1954 é um tempo razoável, sobretudo numa época que havia poucos antropólogos. A primeira Reunião Brasileira de Antropologia foi realizada no Museu Nacional em 1953, quando estava concluindo meu curso de Filosofia na USP. Nessa ocasião teria surgido a idéia para a criação da ABA, a Associação Brasileira de Antropologia. Em 1955, durante a segunda Reunião Brasileira de Antropologia, a $\mathrm{ABA}$ foi formalmente instituída. E nessa época não havia muito mais do que uma dezena de antropólogos profissionais no Brasil. Eu era o "jovem" antropólogo. Enquanto todos eram professores, fulano e beltrano, Roberto Cardoso aparecia como "licenciado Roberto Cardoso", era apenas "lic." ( risos ). Eu não tinha status para poder ser professor, e é muito interessante isso porque é revelador do mandarinato da época! Mas apesar de tudo isso, acabei fazendo parte da primeira diretoria da ABA.

Etienne Samain: No livro Estilos de antropologia (1995), na parte final apresentada por Mariza Corrêa, eles lembram disso, existe até uma fotografia... se tiver boa memória... 
Etienne Samain e João M. De Mendonça. Diálogos com Roberto Cardoso de Oliveira

Roberto Cardoso de Oliveira: Eu sei que o Darcy era secretário e eu o tesoureiro (risos). E lá aparece "professor", digamos, "Luiz de Castro Faria-Presidente", "Professor Darcy Ribeiro-Secretário Geral", "Tesoureiro - ... Licenciado Roberto Cardoso", nem ao menos escreviam meu nome completo... (risos).

Então você vê, como sou testemunha e participei desde o início da ABA, essa coisa vai se acumulando e eu fui guardando. Então doei isso. Quanto às fotos pelas quais vocês têm um interesse especial, devo dizer que as dei mais com uma preocupação de salvá-las; eu sabia que na forma como eu as guardava em minha casa, no meu apartamento, elas estavam ameaçadas de estragar. Eu as reuni ao acervo como uma maneira de conservá-las. Naépoca havia uma moça muito competente que trabalhava com fotografias, esqueci o nome dela. Era uma bolsista da CAPES: ela era formada em antropologia e com gosto para o trabalho de arquivo fotográfico. Trabalhou um bom tempo com minha coleção fotográfica.

Eu quis, naturalmente, colocar em boas mãos as fotos que hoje pertencem à Unicamp e estão abertas à consulta de pessoas academicamente qualificadas a juízo da direção do Arquivo Edgard Leuenroth. Parece que tem sido usado várias vezes. Há uma tese de doutorado que usou muito o meu material, e eu sei porque fiz parte da banca. Soube que algumas outras pessoas recorreram ao acervo. É pena que ele ainda não esteja devidamente informatizado, o que facilitaria bastante sua consulta. E nem sei quando essa informatização vai acontecer. Mesmo para mim, é difícil consultá-lo hoje em dia dada à sua ampliação. Tentei convencer o Castro Faria a doar o material dele porque, se tenho um material que cobre um período razoável, o que dizer do acervo do Castro Faria! Abarca um período bem maior... Mas ele, bem ao seu estilo, diz: "Não, quando eu morrer, eu mando rasgar, eu mando queimar...". E estou tentando, também, para colaborar com a Mariza, fazer com que o David Maybury-Lewis também doe o seu material. Mas há de se reconhecer que meus colegas são meio complicados... Há uma certa resistência, talvez para não se revelar demasiadamente, pois um acervo de documentos tem sempre uma dimensão pessoal. 
Bom, pelo menos eu colaborei desde o início com esse projeto. Não fui o único, pois o Donald Pierson teve o maior prazer em doar uma parte de seu material. O Charles Wagley também andou doando para o projeto. Mas só Mariza poderá informar bem sobre isso. Só não sei atualmente como as coisas estão, não converso há algum tempo com Mariza, e não sei se ela tem dado prosseguimento ao projeto sobre a História da Antropologia no Brasil, porque vejo que ela está tão vinculada à antropologia de gênero e temo que isso tenha ficado em segundo plano, seria uma pena!

Etienne Samain: Mas são coisas que, às vezes, são rápidas de serem retomadas, não é?

Roberto Cardoso de Oliveira: Pois é, mas eu acho que ela podia pelo menos ter o staff, com algumas pessoas fazer alianças, inclusive com vocês e com outros, para tentar conseguir que o acervo cresça. Mas não quero me intrometer...

Etienne Samain: Vou tentar falar disso com ela.

Roberto Cardoso de Oliveira: E isso é um trabalho de muitos, não é de uma pessoa só, é de um grupo. Não é?

Etienne Samain: Professor Cardoso, já são quase nove horas, eu vou fazer ainda uma pequena pergunta. $\mathrm{O}$ senhor me disse que, segunda-feira próxima (25 de maio de 1998), vai precisamente, no Rio de Janeiro, fazer uma palestra sobre os Tükúna no "clube" dos "Ticunólogos" e que, para tanto, foi um prazer poder mergulhar nos seus diários. Então para iniciar, e pensando num trabalho futuro do senhor com esse distanciamento que tem com relação aos Tükúna, será que, porventura, gostaria de ter estas fotografias (reproduções feitas por João Martinho de parte do acervo fotográfico de Robeto Cardoso de Oliveira na Unicamp)? 
Roberto Cardoso de Oliveira:Ah, sim. Ele (JM) colocou uma questão nessa direção, sobre o que poderia fazer com este material dos arquivos... Bem, eu tenho pensado nesses últimos meses. Tinha uma idéia meio vaga mas a partir do momento em que o professor João Pacheco de Oliveira me convidou para fazer a palestra de abertura deste simpósio sobre os Tükúnas, então me veio a idéia. O que poderia falar aos jovens que estão trabalhando com os Tükúna num momento em que já não trabalho com eles há tanto tempo? Eu tenho trabalhado nestas duas últimas décadas com questões de epistemologia, de etnicidade e de moralidade em termos teóricos, mas não tenho feito etnologia. A última etnologia que fiz - se é que posso classificar meu trabalho como etnologia - foi na Catalunha, escrevendo sobre a identidade catalã e a ideologia da Catalanidad; porém uma pesquisa mais de biblioteca e de arquivos, e com uma ou outra entrevista.

Achei, então, que seria interessante tomar o primeiro diário Tükúna, e daí o título da palestra que vou proferir: "Tükúna/1959. Excertos de um diário de campo". De poder falar sobre alguns dados desse diário, passar um pouco aos alunos o que era a área e como era a pesquisa na região do alto rio Solimões. Eu falo um pouco sobre como ser aprendiz de botânica, sobre como e porque fazer um herbário, pois tive que aprender fazer herbário e plantas utilizadas para a manufaturação do curare, esse veneno que os Tükúna faziam tão bem. E foi graças à etnografia da produção do curare que eu consegui verba para a pesquisa de 1959, concedida pela Divisão de Botânica do Museu Nacional e pelo CNPq. Passar para eles um pouco dessas experiências e sobre o que era a região e as próprias condições de pesquisa, pareceram-me que poderiam ser de interesse a antropólogos que, muitos deles, ainda nem eram nascidos...

Porque antes de mim quem tinha feito etnografia na região? Pesquisa profissional só mesmo a do Curt Nimuendajú. A etnografia de Nimuendajú é dos anos 40, e ele lá haveria de morrer em 1946. Comigo eles teriam a oportunidade de ouvir um depoimento sobre a segunda década dos anos 50 , no final. Eu bem poderia estender até os anos 60, melhor diria, o ano 62, ou, ainda, a 1975, minha última ida à área Tükúna, mas ficaria muito pesada e extensa a palestra. Preferi me restringir à minha primeira ida ao 
Revista de Antropologia, São Paulo, USP, 2000, v. 43 nº 1.

campo. Tenho, portanto, vários diários. Assim, tive que reler os dois volumes do diário de 1959. E ao fazer a re-leitura, cheguei a pensar em fotos... estava pensando nos dados do diário. Além do mais, como vocês sabem, a documentação fotográfica não está mais comigo, está na Unicamp. Mas, com essa nossa conversa - e eu sabendo que esse material está lá à disposição para consulta, creio que vale a pena dar uma olhada, quem sabe se não seria interessante editar ao menos uma parte desse diário? E olhar não só o material Tükúna, mas também a documentação Terêna. Vai ser bom rever o material Terêna porque talvez eu me anime a fazer um livro não só sobre os Tükúna, mas fazer sobre ambas etnias, articular as duas em um único volume. E tentar também refletir sobre os Terêna buscando presentificá-los por meio de uma interpretação a partir do meu horizonte atual, como antropólogo e como pessoa. Será como trazê-los dos anos 1955, 57, 58 e 62 - anos da pesquisa de campo - até o presente. Um bom desafio! Então quem sabe se, no futuro, sabendo do interesse de vocês por essa documentação fotográfica, não poderíamos fazer algo em colaboração no que diz respeito aos Terêna...

Mas uma das coisas que gostaria de refletir, já por minha conta e risco, é sobre a própria questão da fotografia como ilustração trivial do texto ou como "discurso imagético" propriamente dito, enfim qualquer coisa nessa direção, como algo a pensar. Eu entendo que a foto permite uma grande evocação. E a evocação é essa presentificação de que falei, quer dizer, você vê coisas de que já não lembra, é muito interessante que, quando olhando uma fotografia antiga, nós nos transportamos no tempo também, mas com outros olhos. Ao se transportar ao tempo congelado na foto, já não se é a mesma pessoa, é uma outra - e é essa que é a chave de toda interpretação, não é?

João Martinho de Mendonça: Pensando na antropologia feita no Brasil, me ocorreu agora a questão da crítica pós-moderna em antropologia, desenvolvida nos Estados Unidos e nos países centrais, para citar apenas um nome, o de Stephen Tyler. Nessa perspectiva, numa posição mais extremada, parece que a herança colonial e cientificista desqualifica a 
Etienne Samain e João M. De Mendonça. Diálogos com Roberto Cardoso de Oliveira

continuidade do empreendimento exigindo a ruptura com a tradição da disciplina. Transpareceria aí um tom confessional que teria como penitência a própria retratação e anulação.

Sabemos que o senhor escreveu sobre as chamadas antropologias periféricas, procurando distinguir nuanças significativas na designação geral da disciplina. Talvez pensando mais especificamente no caso brasileiro, em quais aspectos os trabalhos desenvolvidos aqui guardariam peculiaridades que tornariam esta crítica pós-moderna talvez um pouco ou um tanto inadequada?

Roberto Cardoso de Oliveira: Essa não é uma pergunta fácil de responder. E uma boa resposta exigiria um ensaio! Mas posso adiantar que não considero as antropologias diferenciadas em "tradicionais" e "pós-moderna" como antípodas irreconciliáveis. Se você levar em conta o que venho escrevendo desde Sobre o pensamento antropológico de 1988 até $O$ trabalho do antropólogo, editado mais recentemente, verificará que a preocupação com a objetividade cientificista das primeiras pode bem se complementar com a preocupação com a intersubjetividade da segunda, com seu humanismo e com seu interesse pelo discurso (daí a importância que ela dá à crítica literária). É quando a obsessão com a explicação nomológica das primeiras, concilia-se com a busca da compreensão dessa última. A rigor, poder-se-ia dizer que há uma verdadeira articulação da imaginação científica, estimulada pelas ditas antropologias tradicionais (leia-se: paradigmas "da ordem" ou objetivistas) com a imaginação artística - ou com a poiesis - realizada via o exercício da compreensão hermenêutica (da qual nem sempre os pós-modernos têm consciência...). Como tenho escrito, a antropologia moderna, isto é, atual, vive a tensão entre seus múltiplos paradigmas, todos suscetíveis de serem abrigados - pois coexistentes - numa mesma "matriz disciplinar" altamente dinâmica no que diz respeito às relações entre esses mesmos paradigmas no interior da matriz. 
Revista de Antropologia, São Paulo, USP, 2000, v. 43 nº 1.

João Martinho de Mendonça: Professor, apenas para esclarecimento. O livro de Nimuendajú tenho chamado de uma "etnografia descritiva". Quanto ao seu livro, existe uma passagem do final do primeiro capítulo em que, "com o receio de usar etiquetas", o senhor o chama de "ensaio de "etnologia fenomenológica". O que o senhor diria sobre esta denominação, o senhor manteria isto hoje...?

Roberto Cardoso de Oliveira: Não sei se valeria a pena manter o termo ensaio, para distingui-lo das etnografias descritivas que, à época, se inscreviam no gênero monografia. Já o ensaio não tinha a mesma preocupação das monografias, elaboradas para cumprir uma espécie de itinerário, como de resto a grande maioria das monografias clássicas cumpriam. Você tinha uma história, um ambiente físico, uma organização social, organização econômica, religião, mitologia, e daí em diante. A receita disso estava no clássico Notes and Queries on Anthropology, editado pelo comitê da Royal Anthropological Institution em múltiplas edições (a minha já era a sexta edição), um verdadeiro catálogo de tópicos para a descrição etnográfica. O antropólogo estava imbuído em descrever tudo, então classificava quase tudo que o Notes \& Queries indicava. Raramente havia uma idéia central, e, quando havia, ela praticamente submergia sob os itens do catálogo. É aí que eu via a diferença com o gênero ensaio.

Eu usava "ensaio" porque já tinha uma idéia central, a da "fricção interétnica" e a problemática que ela envolvia; era com isso que eu queria trabalhar. E isso distinguia radicalmente o meu trabalho com o de Nimuendajú, nesse sentido bem tradicional, em que pese a insuperável qualidade de sua etnografia. Então, com aquela idéia e com os dados colhidos em sintonia com ela, eu construí o livro. Lendo o livro o leitor pode verificar que o material etnográfico e sociográfico se aglutinava em torno de uma idéia central. Daí o caráter ensaístico que eu pretendi imprimir naquilo que hoje em dia - concordo - se poderia chamar sem maiores equívocos de monografia. E por quê?

Hoje em dia as monografias com este teor, isto é, centralizadas em idéias, já se constituíram em padrão de investigação etnográfica moderna, e cujos 
Etienne Samain e João M. De Mendonça. Diálogos com Roberto Cardoso de Oliveira

predecessores pioneiros foram antropólogos como o próprio Malinowski, Evans-Pritchard, Leach, sem esquecer Bateson, com seu magnífico Naven! Talvez por esse motivo é que autores como esses sejam os nossos clássicos. Mas, dentre todos esses antropólogos, devo confessar que aquele a chamar mais fortemente a minha atenção, logo após eu haver escrito $O$ índio e o mundo dos brancos, foi a monografia de Victor Turner, de 1957, Schism and Continuity in an African Society e que eu só li posteriormente. O que faz o Victor Turner? Ele tem uma idéia central, a da fissão entre os grupos, e, através dessa idéia, procura interpretar a sociedade africana dos Ndembu. Portanto, o que chamava de ensaio podia passar facilmente por uma monografia, ainda que bem distinta, em concepção, da de Curt Nimuendajú, The Tukuna, de 1952.

Com relação à segunda parte de sua pergunta, do por quê da expressão "etnologia fenomenológica", responderei brevemente para compensar a extensa resposta que dei sobre a primeira parte. Tratava-se de investigar o sistema de representações dos Tükúna, inquirindo o próprio pensamento indígena, identificando suas categorias, porém animado - que eu estava então - com o trabalho de Lukàcs, notadamente seu Histoire et Conscience de Classe (1960), lido em sua tradução francesa. Eu queria dar conta da "consciência infeliz" (esse importante conceito da fenomenologia hegeliana), a saber, uma consciência dividida em duas, alienada, como a do caboclo (ou o índio aculturado) que é um índio que se vê com os olhos etnocêntricos do "branco" regional. Nessa época imaginava articular a antropologia social com a fenomenologia do jovem Marx através do estudo de ideologias. A identidade étnica para mim era e continua sendo uma ideologia. Mas só posteriormente, já nos anos 70, descobri que a melhor maneira de dar conta das identidades étnicas era por meio do conceito de etnicidade. Nesse sentido, a obra de Barth, entre outros, me ajudou muito e me levou a escrever Identidade, etnia e estrutura social, publicado em 1976.

João Martinho de Mendonça: No início da entrevista o senhor falou sobre o controle da veracidade através da relação dialógica em oposição 
a uma "forma perversa da procura de objetividade" que seria o objetivismo. Trata-se evidentemente da perspectiva hermenêutica, minha pergunta seria sobre as mudanças que esta forma de abordar a questão do conhecimento acarretaria no processo educacional. Isto na medida em que novas tecnologias imagéticas são desenvolvidas contribuindo igualmente para a modificação das relações tradicionais no ensino. Faço a pergunta pensando, é claro, na sua experiência também como professor.

Roberto Cardoso de Oliveira: A objetividade absoluta a todo custo como alvo maior da explicação antropológica é que resultaria na perversão da busca de objetividade que, em si mesma, deve continuar como uma idéia reguladora da investigação científica, portanto perfeitamente válida como um alvo a ser perseguido pela pesquisa esclarecida. Como mencionei há pouco, ela, assim, concebida, se concilia com a própria compreensão hermenêutica.

Quanto à questão da relação dialógica, como base de negociação interpares da veracidade, termo este que eu prefiro como substituto da palavra verdade, por contornar mais facilmente questões metafísicas, não saberia lhes dizer como as tecnologias imagéticas poderão contribuir para isso! Como tais tecnologias poderão favorecer o exercício pleno da argumentação voltada para a construção de consenso? É um desafio para os antropólogos visuais e para os educadores.

João Martinho de Mendonça: Agora, apenas para finalizar, quero pedir ao senhor para nos contar um pouco sobre a sua experiência com Heinz Foerthmann no filme Kuarup. Como foi a sua participação nesta história?

Roberto Cardoso de Oliveira: Minha participação foi marginal ao excelente trabalho cinematográfico do Henrique - como o chamávamos ao tempo do Museu do Índio. Apenas lhe disse que não haveria melhor texto para o documentário do que o próprio mito do Kuarup. O que ele 
Etienne Samain e João M. de Mendonça. Diálogos com Roberto Cardoso de Oliveira

fez foi registrar o ritual, cabendo a mim apenas articular o rito com uma das versões do mito, aquela que melhor traduziria para o espectador a performance dos participantes do Kuarup. Não tenho muito mais a acrescentar, senão dizer que foi um prazer ter trabalhado com Heinz Forthmann, um saudoso e grande amigo.

Etienne Samain: Professor Cardoso, muito obrigado... pela sua generosidade intelectual tanto quanto humana.

Campinas, abril de 1999.

\section{Bibliografia}

ADORNO, T.

1992

Minima Moralia, São Paulo, Ática, pp.21.

BATESON, G.

1965

Naven. A survey of the problems suggested by a composite picture of the culture of New Guinea tribe drawn from three points of view, Stanford University Press.

CORRÊA, M.

1987

História da Antropologia no Brasil (1930-1960): testemunhos de Emilio Willens e Donald Pierson, São Paulo, Vértice.

DUMONT, L.

1985 Homo Aequalis. Genèse et Épanouissement de L'idéologie Économique, Paris, Gallimard. 
FARIA, L. C.

1993

Antropologia: espetáculo e excelência, Rio de Janeiro, Ed. UFRJ/ Tempo Brasileiro.

\section{GEERTZ,C.}

1998[1997/98] Works and Lives: Anthropologist as author, Stanford University Press. [Tradução portuguesa parcial (de Fraya Frehse) "Os dilemas do antropólogo entre 'estar lá 'e 'estar aqui'”, in Cadernos de Campo, Ano 8, São Paulo (USP), pp. 202-35].

\section{GOODY, J.}

1988[1977] A domesticação do pensamento selvagem, Lisboa, Presença. [The Domestication of the Savage Mind, Cambridge, University Press].

\section{LÉVI-STRAUSS, C.}

1976 O pensamento selvagem, São Paulo, Ed. Nacional.

1982 As estruturas elementares do parentesco, Petrópolis, Vozes.

1994 Saudades do Brasil, São Paulo, Companhia das letras.

1996 Tristes trópicos, São Paulo, Companhia das Letras.

1997[1995] Escutar, olhar, ler, São Paulo, Companhia das Letras. [Écouter, Regarder, Lire, Paris, Plon].

\section{LUKÁCS, G.}

1960 Histoire et Conscience de Classe. Éssais de Dialectique Marxiste, Paris, Les Éditions de Minuit.

MALINOWSKI, B.

1922 [1976] Argonauts of the Western Pacific - an account of native enterprise and adventure in the archipelagoes of Melanesian New Guinea, 
Etienne Samain e João M. de Mendonça. Diálogos com Roberto Cardoso de Oliveira

Londres, Routledge \& Kegan Paul. [Tradução portuguesa: São Paulo, Abril Cultural, Col. Os Pensadores, XLIII].

1929[1982] The Sexual Life of Savages in North-Western Melanesia. An Ethnographic account of courtship, marriage and family life among the natives of the Trobriand islands New Guinea, Londres, Routledge \& Kegan Paul. [Tradução portuguesa: Rio de Janeiro, Francisco Alves].

1935 Coral Gardens and their Magic: V.1. Soil-tilling and agricultural rites in the Trobriand islands; V.2. The language of magic and gardening, Londres, George Allen \& Unwin.

MEAD, M. \& BATESON, G.

1942 Balinese Character. A photographic analysis, The New York Academy of Sciences.

NIMUENDAJÚ, C.

1952 The Tukuna, Berkeley and Los Angeles, University of California Publications in American Archaeology and Ethnology, XLV.

OLIVEIRA, R.C.

1960 Oprocesso de assimilação dos Terêna, Rio de Janeiro, Museu Nacional.

$1964 \quad O$ índio e o mundo dos brancos: a situação dos Tükúna do alto Solimões, São Paulo, Difusão Européia do Livro, Coleção Corpo e Alma do Brasil.

1968 Urbanização e tribalismo - a integração dos Terêna numa sociedade de classes, Rio de Janeiro, Jorge Zahar.

1976 a Identidade, etnia e estrutura social, São Paulo, Pioneira.

1976 b Do índio ao bugre. O processo de assimilação dos Terêna, Rio de Janeiro, Francisco Alves.

1983 Enigmas e soluções - exercícios de etnologia e de crítica, Rio de Janeiro, Tempo Brasileiro. 
Revista de Antropologia, São Paulo, USP, 2000, v. 43 nº 1.

1988 a A crise do indigenismo, Campinas, Ed. Unicamp.

1988 b Sobre o pensamento antropológico, Rio de Janeiro, Tempo Brasileiro.

1994 Razão e afetividade : o pensamento de Lévy-Bruhl, Campinas, Ed. Unicamp.

1996 "O trabalho do antropólogo: olhar, ouvir, escrever", Revista de Antropologia-USP, vol. 39(1).

1998 a O trabalho do antropólogo, São Paulo, Ed. Unesp.

1998 b "Tükúna/1959. Excertos de um diário de campo", comunicação apresentada na abertura do Encontro de Pesquisadores "Os Ticuna hoje: direções e perspectivas da pesquisa etnológica”, de 25 a 27 de maio de 1998, no Museu Nacional da Universidade Federal do Rio de Janeiro (UFRJ), sob coordenação de João Pacheco de Oliveira Filho. Promoção: Projeto "Universo Ticuna: território, saúde e meio ambiente" (FINEP/PPG-7).

OLIVEIRA, R. C. \& RUBEN, G. R. (orgs.)

1995 Estilos de antropologia, Campinas, Ed. Unicamp.

PINNEY,C.

1996 [1992] “A história paralela da Antropologia e da Fotografia", in PEIXOTO, C. \& MONTE-MÓR, P. (eds.), Cadernos de Antropologia e Imagem 2. Antropologia e fotografia, Rio de Janeiro, PPCIS/UERJ/NAI, pp. 29-52. ["The Parallel Histories of Anthropology and Photography" in, EDWARDS, E. (ed.), Anthropology and Photography 1860-1920, New Haven and London, Yale University Press in association with The Royal Anthropological Institute, pp. 74-95].

RICOEUR, $P$.

1949[1971] "Royal Anthropological Institute of Great Britain and Ireland", Notes and Queries on Anthropology, 6 ed. [Tradução portuguesa: São Paulo, Cultrix].

1969 Les Conflits des Interprétations. Éssais d'herméneutique, Paris, Seuil. 
Etienne Samain e João M. de Mendonça. Diálogos com Roberto Cardoso de Oliveira

1987 Teoria da interpretação. O discurso e o excesso de significação, Lisboa, Edições 70.

Du Texte à l'Action. Essais d'herméneutique II, Paris, Seuil, ewww.

SAMAIN, E. (org.)

1998 O fotográfico, São Paulo, Hucitec/ CNPq.

SAMAIN, E.

1994

"Oralidade, escrita, visualidade. Meios e modos de construção dos indivíduos e das sociedades humanas", in Soc. Bras. De Psicanálise de S.P. (org.), Perturbador mundo novo. História, psicanálise e sociedade contemporânea. 1492 - 1900 - 1992, São Paulo, Escuta, pp. 289-301.

1995 “'Ver' e 'dizer' na tradição etnográfica: Bronislaw Malinowski e a fotografia", in ECKERT, C. \& GODOLPHIN, N. (orgs.), Horizontes antropológicos. Antropologia Visual, n. 2, Porto Alegre, PPGAS/ UFRGS, pp. 19-48.

1998 a "No fundo dos olhos: os futuros visuais da antropologia", in PEIXOTO, C. \& MONTE-MÓR, P. (eds.), Cadernos de Antropologia e Imagem 6. Imagens diversas, Rio de Janeiro, PPCIS/UERJ/NAI, pp. 141-58.

1998 b "Questões heurísticas em torno do uso das imagens nas ciências sociais", in FELDMAN-BIANCO, B. \& LEITE, M. L. M. (orgs.), Desafios da imagem. Fotografia, iconografia e vídeo nas ciências sociais, Campinas, Papirus, pp. 51-62.

SPERBER,D.

1996 La Contagion des idées, Paris, Odile Jacob.

TURNER, V.

1957 Schism and Continuity in an African Society. A Study of Ndembu Village Life, Manchester University Press. 
TYLER, $S$.

1986 "Post-modern ethnography: From document of the occult to occult document", in CLIFFORD, J. \& MARCUS, G. (org.), Writing Culture - The Poetics and Politics of Ethnography, Berkeley, University of California Press.

\section{Referências Imagéticas}

FOERTHMANN, H. K.

1963 Filme etnográfico, INCE (Instituto Nacional do Cinema Educativo), texto e nota etnográfica de Roberto Cardoso de Oliveira.

MINELLI, C.

1994 Amazônia, Bologna, Ed. Grafis, pp. 57- 68 (fotografias coloridas de Luciano Bitelli, a capa do livro apresenta a imagem do rosto da moça nova com adornos rituais plumísticos).

NIMUENDAJÚ, C.

1952

The Tükúna, Berkeley and Los Angeles, University of California Publications, American Archaeology and Ethnology, XLV, pp. 169205 (18 pranchas com 55 fotografias classificadas).

\section{OLIVEIRA FILHO, J.P.}

1998 Exposição fotográfica apresentada no encontro de pesquisadores "Os Ticuna hoje: direções e perspectivas da pesquisa etnológica”, de 25 a 27 de maio de 1998, no Museu Nacional da Universidade Federal do Rio de Janeiro (UFRJ), sob coordenação de João Pacheco de Oliveira Filho. Promoção: Projeto "Universo Ticuna: território, saúde e meio ambiente" (FINEP/PPG-7). 
Etienne Samain e João M. de Mendonça. Diálogos com Roberto Cardoso de Oliveira

OLIVEIRA, R. C.

Acervo fotográfico - Arquivo Edgard Leuenroth/IFCH/Unicamp. As fotografias da expedição ao rio Alto Solimões em 1959, publicadas parcialmente nas edições do livro $O$ índio e o mundo dos brancos foram reproduzidas para o projeto "A imagem dos Tükúna no contexto de um trabalho antropológico: as fotografias de Roberto Cardoso de Oliveira", desenvolvido pelo mestrando João Martinho de Mendonça sob orientação do Prof. Dr. Etienne Samain no âmbito do departamento de Multimeios da Unicamp.

RONDON, C. M. da S.

1953 Índios do Brasil, norte do rio Amazonas, Rio de Janeiro, Conselho Nacional de Proteção aos Índios, Ministério da Agricultura, vol. III, pp. 237-240 (prancha com 6 fotos e comentários nas legendas). 